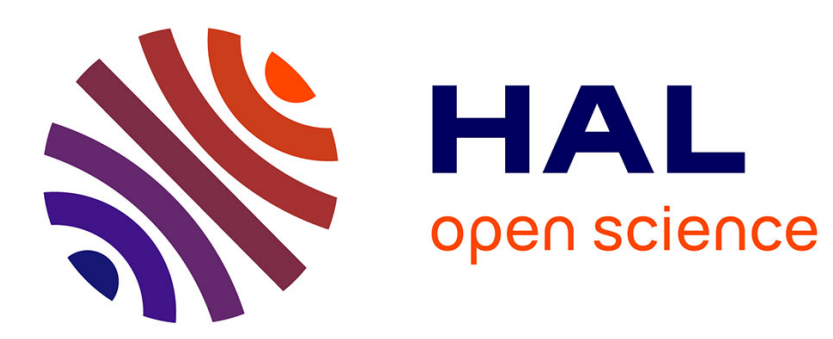

\title{
The endocannabinoid 2-arachidonylglycerol is a negative allosteric modulator of the human A adenosine receptor
}

\author{
J. Robert Lane, Margot W. Beukers, Thea Mulder-Krieger, Ad P. Ijzerman
}

\section{To cite this version:}

J. Robert Lane, Margot W. Beukers, Thea Mulder-Krieger, Ad P. Ijzerman. The endocannabinoid 2arachidonylglycerol is a negative allosteric modulator of the human A adenosine receptor. Biochemical Pharmacology, 2009, 79 (1), pp.48. 10.1016/j.bcp.2009.07.024 . hal-00529100

\section{HAL Id: hal-00529100 https://hal.science/hal-00529100}

Submitted on 25 Oct 2010

HAL is a multi-disciplinary open access archive for the deposit and dissemination of scientific research documents, whether they are published or not. The documents may come from teaching and research institutions in France or abroad, or from public or private research centers.
L'archive ouverte pluridisciplinaire HAL, est destinée au dépôt et à la diffusion de documents scientifiques de niveau recherche, publiés ou non, émanant des établissements d'enseignement et de recherche français ou étrangers, des laboratoires publics ou privés. 


\section{Accepted Manuscript}

Title: The endocannabinoid 2-arachidonylglycerol is a negative allosteric modulator of the human $\mathrm{A}_{3}$ adenosine receptor

Authors: J. Robert Lane, Margot W. Beukers, Thea Mulder-Krieger, Ad P. IJzerman

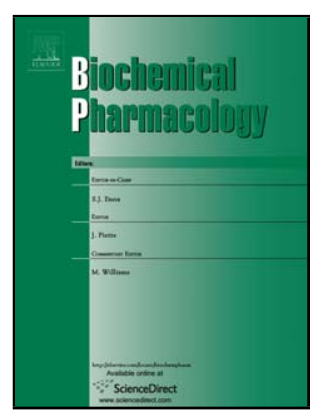

PII: S0006-2952(09)00677-7

DOI: doi:10.1016/j.bcp.2009.07.024

Reference: BCP 10281

To appear in: $\quad B C P$

Received date: 6-4-2009

Revised date: $\quad 16-7-2009$

Accepted date: $\quad$ 31-7-2009

Please cite this article as: Lane JR, Beukers MW, Mulder-Krieger T, IJzerman AP, The endocannabinoid 2-arachidonylglycerol is a negative allosteric modulator of the human $\mathrm{A}_{3}$ adenosine receptor, Biochemical Pharmacology (2008), doi:10.1016/j.bcp.2009.07.024

This is a PDF file of an unedited manuscript that has been accepted for publication. As a service to our customers we are providing this early version of the manuscript. The manuscript will undergo copyediting, typesetting, and review of the resulting proof before it is published in its final form. Please note that during the production process errors may be discovered which could affect the content, and all legal disclaimers that apply to the journal pertain. 
Title Page

The endocannabinoid 2-arachidonylglycerol is a negative allosteric modulator of the human $A_{3}$ adenosine receptor

J. Robert Lane, Margot W. Beukers, Thea Mulder-Krieger, Ad P. IJzerman

Division of Medicinal Chemistry, Leiden/Amsterdam Centre for Drug Research, Leiden University, P.O.Box 9502, 2300 RA Leiden, The Netherlands

J. Robert Lane

Division of Medicinal Chemistry, Leiden/Amsterdam Centre for Drug Research, Leiden University, P.O.Box 9502, 2300 RA Leiden, The Netherlands

Phone: $+31-(0) 715274268$

Fax: $+31-(0) 715274565$

jrlane@chem.leidenuniv.nl 


\section{Abstract}

Studies of endogenous cannabinoid agonists, such as 2-arachidonylglycerol (2-AG), have revealed their potential to exert modulatory actions on other receptor systems in addition to their ability to activate cannabinoid receptors. This study investigated the effect of cannabinoid ligands on the human adenosine $A_{3}\left(h A_{3} R\right)$ receptor. The endocannabinoid 2-AG was able to inhibit agonist ([ $\left.{ }^{125} \mathrm{I}\right] \mathrm{N} 6-(4-$ amino-3-iodobenzyl) adenosine-5'-(N-methyluronamide) - $\left[{ }^{125} \mathrm{I}\right] \mathrm{AB}$ MECA) binding at the $\mathrm{h} \mathrm{A}_{3} \mathrm{R}$. This inhibition occurred over a narrow range of ligand concentration and was characterized by high Hill coefficients suggesting a non-competitive interaction. Furthermore, in the presence of 2-AG, the rate of $\left[{ }^{125} \mathrm{I}\right] \mathrm{AB}$ MECA dissociation was increased, consistent with an action as a negative allosteric modulator of the $\mathrm{hA}_{3} \mathrm{R}$. Moreover, by measuring intracellular cAMP levels, we demonstrate that 2-AG decreases both the potency of an agonist at the $\mathrm{hA}_{3} \mathrm{R}$ and the basal signalling of this receptor. Since the $\mathrm{hA}_{3} \mathrm{R}$ has been shown to be expressed in astrocytes and microglia, these findings may be particularly relevant in certain pathological states such as cerebral ischemia where levels of 2-AG and anandamide are raised.

Keywords: G protein coupled receptor (GPCR), Adenosine $A_{3}$ receptor, endocannabinoid, 2arachidonylglycerol, allosteric modulation 


\subsection{Introduction}

The cannabinoid and adenosine pathways have overlapping roles in both the modulation of neurotransmitter release in the central nervous system and modulation of the immune response $[1,2]$. The endogenous nucleoside adenosine activates four distinct adenosine receptors, which all belong to the family of G protein coupled receptors (GPCR): the adenosine $A_{1}, A_{2 A}, A_{2 B}$ and $A_{3}$ receptor [1]. Of these the adenosine $A_{3}$ receptor is the most recently discovered and has a wide distribution, with its mRNA being present in testis, lung, heart, placenta, brain, spleen, liver, uterus, proximal colon and bladder [3-5]. There is now extensive evidence for the involvement of the $\mathrm{A}_{3}$ adenosine receptor in many disease pathways [6]. The $\mathrm{A}_{3}$ receptor has been implicated in the modulation of inflammatory effects, for example stimulation of the $\mathrm{A}_{3}$ receptor expressed in RBL-2H3 rat mast cells with adenosine leads to degranulation and may protect mast cells from apoptosis [7]. The $\mathrm{A}_{3}$ receptor also plays an important role in both neuroprotective and neurodegenerative effects in the brain [6].

Of several endogenous agonists for cannabinoid receptors identified thus far the most notable are anandamide and 2-arachidonylglycerol (2-AG) [2]. Their physiological effects are mainly mediated via the cannabinoid receptors $\mathrm{CB}_{1}$ and $\mathrm{CB}_{2}$ [2]. These endocannabinoids have been implicated in both neuromodulatory roles and immunomodulatory functions (e.g. through the regulation of cytokine release and immune cell migration) [8]. $\mathrm{CB}_{1}$ receptor expression levels are highest in the $\mathrm{CNS}$, whereas $\mathrm{CB}_{2}$ receptors have a close association with the immune system and mRNA has been detected in a wide variety of immune cells and tissues such as 
mast cells and microglia [2]. Interestingly, the endocannabinoid 2-AG has been shown to decrease the immunological activation of guinea pig mast cells in a mechanism mediated by $\mathrm{CB}_{2}$ receptors and opposite to the effect mediated by adenosine described above [9]. Consequently, it was of interest to investigate the potential for cannabinoid ligands to modulate the action of the adenosine $\mathrm{A}_{3}$ receptor.

It should be noted that a number of studies have implicated other sites of action of these endocannabinoids in addition to their ability to activate cannabinoid $\mathrm{CB}_{1}$ and $\mathrm{CB}_{2}$ receptors [10]. For example, neurobehavioural studies carried out in cannabinoid $\mathrm{CB}_{1}$ knockout mice showed that regardless of the lack of $\mathrm{CB}_{1}$ receptors, anandamide still exerted cannabimimeticlike activity, even though the $\mathrm{CB}_{1}$ receptor is believed to be the only receptor for cannabinoids in the brain [11]. Interestingly, cannabinoids inhibit the production of cytokines such as tumour necrosis factor- $\alpha$ from activated microglial cells but this activity does not involve any known $\mathrm{CB}$ receptor subtype for it occurs at high concentrations of ligands [12, 13]. Furthermore anandamide has been shown to inhibit ligand binding to central 5-HT receptors and muscarinic acetylcholine receptors [14-16]. In both cases this has been shown to be a direct effect, and not mediated by the interaction of the endocannabinoid with either $\mathrm{CB}_{1}$ or $\mathrm{CB}_{2}$ receptors. This is particularly relevant for disease states such as ischemia and schizophrenia where the local concentration of the endocannabinoid can be elevated [17-20]. Given that cannabinoid receptors and adenosine $\mathrm{A}_{3}$ receptors are co-localised, for example in glia and immune cells such as mast cells $[2,6,21,22]$, it is possible that elevated levels of endocannabinoids may exert a 'spill-over' effect on adenosine receptor binding and/or functional properties. In the present study we focus on the $\mathrm{hA}_{3}$ receptor and demonstrate that the endocannabinoid ligands do indeed have a direct effect on the ligand binding of $\mathrm{hA}_{3}$ receptors. Furthermore, this study provides evidence that this interaction is non-competitive 
and independent of an interaction with either $\mathrm{CB}_{1}$ or $\mathrm{CB}_{2}$ receptors. The inhibition of both agonist and antagonist binding is characterised by steep Hill slopes over a narrow concentration range. This effect is specific to the $\mathrm{A}_{3}$ receptor, with no effect of cannabinoid ligands being observed on the ligand binding ability of $\mathrm{A}_{1}$ or $\mathrm{A}_{2 \mathrm{~A}}$ adenosine receptors. Moreover, measuring intracellular cAMP levels, we demonstrate that 2-AG decreases both the potency of an agonist at the $\mathrm{hA}_{3} \mathrm{R}$ and the basal signalling of this receptor. An investigation of ligand dissociation kinetics demonstrated that eicosanoid ligands, including the endogenous ligands anandamide and 2-AG, are negative allosteric modulators of ligand binding at the adenosine $\mathrm{A}_{3}$ receptor.

\section{Materials and Methods}

\subsection{Materials}

$\left[{ }^{125} \mathrm{I}\right] \mathrm{AB}$ MECA was purchased from Perkin Elmer BV, Groningen, NL. The following cannabinoid ligands were obtained from Tocris Ltd., Avonmouth, UK: ACEA, N-(2Chloroethyl)-5Z,8Z,11Z,14Z-eicosatetraenamide; ACPA, N-(Cyclopropyl)-5Z,8Z,11Z,14Zeicosatetraenamide; AM251, N-(Piperidin-1-yl)-5-(4-iodophenyl)-1-(2,4-dichlorophenyl)-4methyl-1H-pyrazole-3-carboxamide; AM630, 6-Iodo-2-methyl-1-[2-(4-morpholinyl)ethyl]1H-indol-3-yl](4-methoxyphenyl)methanone; CP55940,(-)-cis-3-[2-Hydroxy-4-(1,1dimethylheptyl)phenyl]-trans-4-(3-hydroxypropyl)cyclohexanol; GW 405833, 1-(2,3Dichlorobenzoyl)-5-methoxy-2-methyl-3-[2-(4-morp holinyl)ethyl]-1H-indole; JWH 133, (6aR,10aR)-3-(1,1-Dimethylbutyl)-6a,7,10,10a-tetrahydro -6,6,9-trimethyl-6Hdibenzo[b,d]pyran; WIN55212-2; $(R)-(+)-[2,3-D i h y d r o-5-m e t h y l-3-(4-$ 


\subsection{Cell culture}

Chinese hamster ovary $(\mathrm{CHO})$ cells stably expressing either the wild type human adenosine $A_{1}$ receptor $\left(h A_{1}\right)$ or the wild type human adenosine $A_{3}$ receptor $\left(h A_{3}\right)$ were grown in a 1:1 mixture of Dulbecco's modified Eagle's medium (DMEM) and Ham's F12 medium containing 10\% newborn calf serum, streptomycin $\left(50 \mu \mathrm{g} \cdot \mathrm{ml}^{-1}\right)$, penicillin $\left(50 \mathrm{IU} \cdot \mathrm{ml}^{-1}\right)$ and G418 (0.2 mg.ml $\left.{ }^{-1}\right)$ at $37^{\circ} \mathrm{C}$ in $5 \% \mathrm{CO}_{2}$. HEK 293 cells stably expressing the wild type human $\mathrm{A}_{2 \mathrm{~A}}$ adenosine receptor were grown in DMEM containing $10 \%$ newborn calf serum, streptomycin $\left(50 \mu \mathrm{g} \cdot \mathrm{ml}^{-1}\right)$, penicillin $\left(50 \mathrm{IU} \cdot \mathrm{ml}^{-1}\right)$ and $\mathrm{G} 418\left(0.5 \mathrm{mg} \cdot \mathrm{ml}^{-1}\right)$ at $37^{\circ} \mathrm{C}$ in $7 \% \mathrm{CO}_{2}$, The cells were subcultured twice weekly at a ratio of 1:20. For all membrane preparations the cells were transferred to large $14 \mathrm{~cm}$ diameter plates.

\subsection{Membrane Preparation}

For all cell lines described above the method of membrane preparation was as follows. Cells were detached from the plates by scraping them into $5 \mathrm{~mL}$ PBS, collected and centrifuged at $200 \times \mathrm{g}(1000 \mathrm{rpm})$ for 5 minutes. Cell pellets derived from 30 plates were pooled and resuspended in $20 \mathrm{~mL}$ of ice-cold $50 \mathrm{mM}$ Tris-HCl buffer, $\mathrm{pH}$ 7.4. An Ultra-Turrax was used to homogenise the cell suspension. The cytosolic and membrane fractions were separated using a high speed centrifugation step of 100,000 x g, (31,000 rpm) in a Beckman Optima LE-80K ultracentrifuge) at $4{ }^{\circ} \mathrm{C}$ for 20 minutes. The pellet was resuspended in $10 \mathrm{~mL}$ of Tris 
buffer and the homogenisation and centrifugation step repeated. The resulting pellet was resuspended in $50 \mathrm{mM}$ Tris-HCl buffer, $\mathrm{pH}$ 7.4. For hA $\mathrm{h}_{1}-\mathrm{CHO}$ and hA $\mathrm{A}_{2 \mathrm{~A}}-\mathrm{HEK} 293$ membrane preparations, adenosine deaminase (ADA) was added to a final concentration of $0.8 \mathrm{IU} / \mathrm{ml}$. For $\mathrm{hA}_{3}-\mathrm{CHO}$ membrane preparations no $\mathrm{ADA}$ was added since the human $\mathrm{A}_{3}$ receptor has a low affinity for adenosine.

2.4 Radioligand binding assays $-\left[{ }^{125} \mathrm{I}\right] \mathrm{AB}$ MECA equilibrium binding assays

CHO membranes expressing either the human adenosine $\mathrm{A}_{1}$ receptor $(10 \mu \mathrm{g} /$ reaction) or the adenosine $\mathrm{A}_{3}$ receptor $(7.5 \mu \mathrm{g} /$ reaction) were incubated with $0.1 \mathrm{nM}$ of the radiolabelled agonist $\left[{ }^{125} \mathrm{I}\right] \mathrm{AB}$ MECA in $50 \mathrm{mM}$ Tris- $\mathrm{HCl}, 10 \mathrm{mM} \mathrm{MgCl}_{2}, \mathrm{pH} 8.0$ with a final volume of $100 \mu \mathrm{L}$. Reactions were incubated for 3 hours at $25^{\circ} \mathrm{C}\left(\mathrm{hA}_{3}-\mathrm{CHO}\right)$ or 2 hours at $25^{\circ} \mathrm{C}\left(\mathrm{hA}_{1}\right.$ $\mathrm{CHO}$ ) and then terminated by rapid filtration through Whatman GF/B filters using a Brandel cell harvester. Filters were washed three times with $4 \mathrm{~mL}$ of ice-cold $50 \mathrm{mM}$ Tris-HCl pH 7.4 and dried before radioactivity was determined using a Beckman 5500B $\gamma$ counter (Perkin Elmer, Shelton, CT). Non specific binding was determined in the presence of $10 \mu \mathrm{M} \mathrm{CPA}$ $\left(\mathrm{hA}_{1}-\mathrm{CHO}\right)$ or $100 \mu \mathrm{M}$ NECA adenosine-5'-N-ethylcarboxamide $\left(\mathrm{hA}_{3}-\mathrm{CHO}\right)$. For saturation binding of $\left[{ }^{125} \mathrm{I}\right] \mathrm{AB}$ MECA to $\mathrm{CHO}$ cell membranes expressing the hA3 receptor, conditions were as above apart from $5 \mathrm{ug}$ of membrane protein was added per reaction and a range of concentrations of $\left[{ }^{125} \mathrm{I}\right] \mathrm{AB}$ MECA was used between $0.025 \mathrm{nM}$ and $5 \mathrm{nM}$.

The ability of NECA, CPA, DPCPX (8-cyclopentyl-1,3-dipropylxanthine) or various cannabinoid ligands to inhibit $\left[{ }^{125} \mathrm{I}\right] \mathrm{AB}$ MECA binding to both $\mathrm{hA}_{1}$ and $\mathrm{hA}$ was also tested. In these experiments stock solutions of the various adenosine receptor ligands or various cannabinoids were prepared at a concentration of $40 \mathrm{mM}$ in DMSO. Subsequent dilutions 
were made in the relevant buffers. Control incubations contained the same concentrations of dimethyl sulfoxide $(1.25 \% \max )$

2. 5 Radioligand binding assays $-\left[{ }^{3} \mathrm{H}\right] \mathrm{ZM} 241385$ equilibrium binding assays

For membranes of HEK 293 cells stably expressing the $\mathrm{hA}_{2 \mathrm{~A}}$ receptor, $\left[{ }^{3} \mathrm{H}\right] \mathrm{ZM} 241385$ (4-(2[7-amino-2- $\{2$-furyl $\}\{1,2,4\}$ triazolo $\{2,3$-a $\}\{1,3,5$,$\} triazin-5-yl amino]ethyl)phenol) was used$ as the radioligand. Membranes containing $40 \mu \mathrm{g}$ of protein were incubated in a total volume of $400 \mu \mathrm{L}$ of $50 \mathrm{mM}$ Tris/ $\mathrm{HCl}\left(\mathrm{pH} 7.4\right.$ ) and $\left[{ }^{3} \mathrm{H}\right] \mathrm{ZM} 241385$ (final concentration $2.0 \mathrm{nM}$ ) for $2 \mathrm{~h}$ at $25^{\circ} \mathrm{C}$ in a shaking water bath. Nonspecific binding was determined in the presence of $100 \mu \mathrm{M}$ CPA. The incubation was terminated by filtration as described above. Radioactivity was determined using a Tri-Carb 2900TR liquid scintillation analyzer (Perkin Elmer, Shelton, $\mathrm{CT})$.

2.6 Radioligand binding assays $-\left[{ }^{3} \mathrm{H}\right]$ PSB-11 equilibrium binding assays

Binding experiments of $4 \mathrm{nM}\left[{ }^{3} \mathrm{H}\right]$ PSB-11 ((8R)-8-Ethyl-1,4,7,8-tetrahydro-4-5Himidazo[2,1-i]purin-5-one) to membranes of $\mathrm{CHO}$ cells expressing human $\mathrm{A}_{3}$ adenosine receptors $\left(50 \mu \mathrm{g}\right.$ of protein per reaction) were carried out in duplicate at $25{ }^{\circ} \mathrm{C}$ for 2 hours in $100 \mu \mathrm{L}$ of buffer containing $50 \mathrm{mM}$ Tris-HCl, $10 \mathrm{mM} \mathrm{MgCl}_{2}, 1 \mathrm{mM}$ EDTA, pH 8.0. Nonspecific binding was defined as that obtained in the presence of $100 \mu \mathrm{M}$ NECA. Tested compounds were dissolved in dimethyl sulfoxide as described above. Reactions were terminated by filtration through GF/B filters on a cell harvester (Brandel, Gaithersburg, MD) 
and radioactivity was determined using a Tri-Carb 2900TR liquid scintillation analyzer (Perkin Elmer, Shelton, CT).

2.7 Dissociation of the radiolabelled, selective agonist $\left[{ }^{125} \mathrm{I}\right] \mathrm{AB}$ MECA from $\mathrm{hA}_{3}-\mathrm{CHO}$ or $\mathrm{hA}_{1}$-CHO membranes

$\left[{ }^{125} \mathrm{I}\right] \mathrm{AB}$ MECA $(0.1 \mathrm{nM})$ was pre-incubated with $\mathrm{hA}_{1}-\mathrm{CHO}$ or $\mathrm{hA}_{3}-\mathrm{CHO}$ membranes for 2 or 3 hours respectively in the reaction buffers described above. Non-specific binding was determined with the addition of $10 \mu \mathrm{M}$ NECA before pre-incubation. Dissociation was initiated by the addition of NECA (final concentration $10 \mu \mathrm{M}$ ) with or without cannabinoid ligands and determined at various time points. Non-specific binding in the presence of tested agents was also determined in parallel. After an additional incubation of 5 hours at $25^{\circ} \mathrm{C}$, the reactions were terminated by filtration through GF/B filters and radioactivity determined as described above.

2.8 Dissociation of the radiolabelled, selective antagonist $\left[{ }^{3} \mathrm{H}\right] \mathrm{PSB}-11$ from $\mathrm{hA}_{3}-\mathrm{CHO}$ membranes

Membranes $\left(60 \mu \mathrm{g} /\right.$ reaction) were incubated with $4 \mathrm{nM}\left[{ }^{3} \mathrm{H}\right] \mathrm{PSB}-11$ in a total assay volume of $100 \mu \mathrm{L}$ for 120 minutes at $25^{\circ} \mathrm{C}$. Dissociation was initiated by the addition of $10 \mu \mathrm{M}$ NECA with or without cannabinoid ligands and determined at various time points after equilibration had been reached. Non-specific binding was determined using $10 \mu \mathrm{M}$ NECA. The reactions were terminated by filtration through GF/B filters and radioactivity determined as described above. 
2.9 cAMP determination.

Intracellular cAMP levels were measured using a LANCE cAMP 384 kit (Perkin Elmer, The Netherlands) as described previously [23]. In short, to each well different concentrations of Cl-IB-MECA (2-Chloro- $N^{6}$-(3-iodobenzyl)-5'- $N$-methylcarbamoyladenosine) in stimulation buffer (PBS with $5 \mathrm{mM}$ Hepes, pH 7.4 supplemented with $0.1 \%$ BSA, rolipram $(50 \mu \mathrm{M})$ and cilostamide $(50 \mu \mathrm{M}))$ was added in a volume of $5 \mu \mathrm{L}$ in the absence (control) or presence of 2-AG or AM 251. Then $4.5 \mu \mathrm{L} \mathrm{CHOhA}_{3}$ cell suspension in stimulation buffer was seeded into a 384-well plate (approximately 5000 cells/well), which was followed by incubation for 15 min at room temperature. Subsequently, $2.5 \mu \mathrm{L}$ forskolin $(1 \mu \mathrm{M})$ was added and the mixture was incubated for $30 \mathrm{~min}$ at room temperature. Finally, $3 \mathrm{~h}$ after adding detection mix $(6 \mu \mathrm{L})$ and cAMP antibody solution $(6 \mu \mathrm{L})$, intracellular cAMP levels were measured using a TRFRET assay on a Victor spectrometer (Perkin Elmer, The Netherlands) according to instructions of the supplier.

\subsection{Data analysis}

Binding parameters were estimated using Graphpad Prism version 5. Data sets of total and non-specific binding assay were analysed simultaneously via non-linear regression. Analysis was performed according to a hyperbolic, one-site mass action binding model to derive individual estimates of total receptor density $\left(\mathrm{B}_{\max }\right)$ and radioligand-receptor equilibrium dissociation constant $\left(\mathrm{K}_{\mathrm{D}}\right)$ as shown in the following equation:

$$
\text { Total binding }=\frac{B_{\max } x}{x+K_{D}}+N S x
$$


Radioligand inhibition binding isotherms were analysed according to the following logistic function:

$$
Y=\frac{(\text { top }- \text { bottom }) x^{n H}}{x^{n H}+I C_{50}^{n H}}
$$

Where Y denotes the percent specific binding, top and bottom denote the maximal and minimal asymptotes respectively, $\mathrm{x}$ denotes the inhibitor potency (midpoint location) parameter and $\mathrm{n}_{\mathrm{H}}$ denotes the Hill slope factor. Where appropriate, and assuming simple competition, $\mathrm{IC}_{50}$ values were converted to $\mathrm{K}_{\mathrm{i}}$ values using the Cheng and Prusoff (1973) equation.

The dissociation of $\left[{ }^{125} \mathrm{I}\right]$ AB MECA and $\left[{ }^{3} \mathrm{H}\right]$ PSB-11 from the human $\mathrm{A}_{3}$ receptor was best described by a mono-exponential decay according to the following equation for monoexponential decay:

$$
Y=(a-b) e^{-k_{o f f} \cdot x}+b
$$

Where a represents the vertical span of the data, $b$ is the plateau value, $x$ is the time ( $\mathrm{min})$, and $\mathrm{k}_{\text {off }}$ is the dissociation rate constant $\left(\mathrm{min}^{-1}\right)$. In contrast the dissociation of $\left[{ }^{125} \mathrm{I}\right] \mathrm{AB}$ MECA from the human $\mathrm{A}_{1}$ receptor was best described by a bi-phasic decay.

In the functional, cAMP accumulation assay, agonist concentration response curves were fitted to the following four-parameter Hill equation using prism 5:

$$
\text { response }=\frac{(\text { top }- \text { bottom })}{1+\left(10^{\log E C_{50}} / x\right)^{n H}}
$$


Where top represents the maximal asymptote of the concentration response curves, bottom represents the lowest asymptote and the concentration-response curves, $\log \mathrm{EC}_{50}$ represents the logarithm of the agonist $\mathrm{EC}_{50}$, $\mathrm{x}$ represents the concentration of the agonist and $\mathrm{n}_{\mathrm{H}}$ represents the Hill slope. Data shown are the mean \pm SEM. Comparisons between models were performed by F-test using Prism. Unless otherwise stated values of $\mathrm{p}<0.05$ were taken as statistically significant. 


\section{Results}

\subsection{Saturation and inhibition binding assays in membranes of CHO cells stably} expressing the human $\mathrm{hA}_{3}$ adenosine receptor

Saturation binding experiments performed for $\left[{ }^{125} \mathrm{I}\right] \mathrm{AB}$ MECA at the $\mathrm{h} \mathrm{A}_{3} \mathrm{R}$ expressed in CHO membranes yielded a $\mathrm{K}_{\mathrm{d}}$ of $1.86 \pm 0.69 \mathrm{nM}$ and a $\mathrm{B}_{\max }$ of $1.16 \pm 0.28 \mathrm{pmol} / \mathrm{mg}$ (Table 2). At the working concentration of $0.1 \mathrm{nM}\left[{ }^{125} \mathrm{I}\right] \mathrm{AB}$ MECA, binding to the $h \mathrm{~A}_{3} \mathrm{R}$ was completely abolished with the addition of $100 \mu \mathrm{M}$ GTP indicating that only the high affinity (G protein-coupled) state of the receptor was occupied at this concentration (data not shown). To examine the effects of various cannabinoid ligands (figure 1) on the binding of $\left[{ }^{125} \mathrm{I}\right] \mathrm{AB}$ MECA to $\mathrm{hA}_{3}-\mathrm{CHO}$ membranes, equilibrium binding experiments were performed. Incubation of $\left[{ }^{125} \mathrm{I}\right] \mathrm{AB}$ MECA with increasing concentrations of either the endocannabinoids 2-AG or anandamide, the structurally related eicosanoid ACPA or the structurally distinct $\mathrm{CB}_{1}$ antagonist AM 251 (N-(Piperidin-1-yl)-5-(4-iodophenyl)-1-(2,4-dichlorophenyl)-4methyl-1H-pyrazole-3-carboxamide) revealed in each case that the cannabinoid ligand was able to compete in a concentration dependent manner with radioligand binding at the $\mathrm{hA}_{3}$ adenosine receptor. $\mathrm{A} \mathrm{pIC}_{50}$ value of approximately 5 was obtained for all three cannabinoid ligands, with ACPA being the most potent (see table 1, figure 2). In every case high Hill coefficients were observed which were significantly larger than and different from unity $(\mathrm{p}<$ 0.05). Since a high Hill slope is not consistent with simple competition $\mathrm{IC}_{50}$ values were not converted to $K_{i}$ values. It should be noted that in the case of both AM 251 and ACPA a full inhibition of $\left[{ }^{125} \mathrm{I}\right]$ AB MECA was observed. However, 2-AG produced a maximum displacement of $80 \%$ of specific $\left[{ }^{125} \mathrm{I}\right] \mathrm{AB}$ MECA binding. Hill coefficients larger than unity 
are suggestive for a non-competitive interaction. We extended this study to include a wider range of cannabinoid ligands. As shown in figure 1 this range included both subtype selective and non-selective antagonists and agonists. All tested cannabinoid ligands, when used at a concentration of $10 \mu \mathrm{M}$, are able to displace $\left[{ }^{125} \mathrm{I}\right] \mathrm{AB}$ MECA, with ACPA (N-(Cyclopropyl)$5 Z, 8 Z, 11 Z, 14 Z$-eicosatetraenamide) producing the most significant effect, displacing $90 \%$ of bound $\left[{ }^{125} \mathrm{I}\right] \mathrm{AB}$ MECA. To determine a rank order this data was analysed using a one-way ANOVA followed by a Bonferroni's post-hoc test. ACPA (N-(Cyclopropyl)-5Z,8Z,11Z,14Zeicosatetraenamide) produced the most significant effect, displacing $90 \%$ of bound $\left[{ }^{125} \mathrm{I}\right] \mathrm{AB}$ MECA consistent with the data shown in Table 1. The remaining rank order in terms of percentage bound $\left[{ }^{125} \mathrm{I}\right] \mathrm{AB}$ MECA displaced was as follows: ACPA>AM251, ACEA, AM 630, 2 AG, anandamide, GW 405833, WIN 55212-2 > JWH 133. Consequently no pattern in terms of the receptor specificity or efficacy of the ligands was observed. Interestingly, the lipid oleamide, an allosteric enhancer at serotonin receptors did not displace bound $\left[{ }^{125} \mathrm{I}\right] \mathrm{AB}$ MECA suggesting that the above effect was not simply a non-specific effect due to high concentrations of lipid (data not shown).

\subsection{Inhibition binding assays in membranes of $\mathrm{CHO}$ cells stably expressing the human} $h A_{1}$ adenosine receptor or $H E K 293$ cells stably expressing the $h A_{2 A}$ adenosine receptor

To investigate the specificity of this effect, this study was extended to a $\mathrm{CHO}$ cell line expressing the $\mathrm{hA}_{1}$ adenosine receptors or a HEK 293 cell line which stably expresses the $\mathrm{hA}_{2 \mathrm{~A}}$ adenosine receptor. For the human $\mathrm{A}_{1}$ receptor, a $10 \mu \mathrm{M}$ concentration of each of the various cannabinoid ligands was unable to inhibit $\left[{ }^{125} \mathrm{I}\right] \mathrm{AB}$ MECA binding. It is interesting to note that cannabinoid ligands can displace $\left[{ }^{125} \mathrm{I}\right] \mathrm{AB}$ MECA at the $\mathrm{hA}_{3} \mathrm{R}$ but not the human $\mathrm{A}_{1}$ receptor. In the case of the $\mathrm{hA}_{2 \mathrm{~A}}$ receptor a $10 \mu \mathrm{M}$ concentration of either ACPA, 2-AG or 
AM 251 was unable to inhibit the binding of the radiolabeled antagonist $\left[{ }^{3} \mathrm{H}\right] \mathrm{ZM} 241385$. This suggests that the effect of cannabinoids on the binding of ligands to the adenosine receptors is specific to the human $\mathrm{A}_{3}$ receptor.

\subsection{Competition binding of $\left[{ }^{125}\right.$ I] AB MECA versus the agonist NECA with and without the presence of the endocannabinoid 2-AG}

In order to gain further insight into the mechanism with which endocannabinoid 2-AG may inhibit ligand binding at the $\mathrm{hA}_{3}$ receptor, competition experiments of $\left[{ }^{125} \mathrm{I}\right] \mathrm{AB}$ MECA binding in the presence of increasing concentrations of NECA were performed with and without the addition of $10 \mu \mathrm{M}$ 2-AG. Although the absolute specific binding of the radioligand was reduced with the addition of $10 \mu \mathrm{M}$ of 2-AG there was no observed effect on the inhibitory potency of NECA (control: $\mathrm{pK}_{\mathrm{i}}=7.17 \pm 0.21,+2-\mathrm{AG} \mathrm{pK}_{\mathrm{i}}=7.02 \pm 0.04$, Student's t-test, $\mathrm{P}>0.05$, Graphpad prism version 5). This again suggests that the endocannabinoid does not compete for the orthosteric site of $\mathrm{hA}_{3}$ receptor and must therefore have an alternative allosteric site of action (figure 3).

\subsection{Saturation binding of $\left[{ }^{125} \mathrm{I}\right] \mathrm{AB}$ MECA to membranes stably expressing the $\mathrm{hA}$ receptor in the presence of increasing concentrations of the endocannabinoid 2-AG}

To further investigate and confirm the non-competitive inhibition of ligand binding at the $\mathrm{hA}_{3}$ adenosine receptor by the endocannabinoid 2-AG, $\left[{ }^{125} \mathrm{I}\right] \mathrm{AB}$ MECA saturation binding 
experiments were performed. These revealed a trend for $2-\mathrm{AG}$ to reduce radioligand maximal binding capacity in a concentration dependent manner. Non-linear regression analysis of the data, followed by F-test demonstrated that the simplest model accommodating all observations was a reduction in $\mathrm{B}_{\max }$ with no change in radioligand affinity with the increasing presence of $2 \mathrm{AG}(\mathrm{p}>0.05)$. Indeed a one way ANOVA analysis followed by a bonferonni post-test revealed that whilst there was no significant difference observed in affinity, there was a significant reduction in $\mathrm{B}_{\max }$ with the addition of 1,3 or $10 \mu \mathrm{M} 2 \mathrm{AG}$ compared to the control condition (Table 2). This is consistent with a non-competitive mode of interaction.

\subsection{Inhibition assays using the radiolabelled antagonist $\left[{ }^{3} \mathrm{H}\right]$ PSB-11}

Although unlikely given the specific nature of the interaction with the $\mathrm{hA}_{3}$ receptor, it is possible that inhibition of ligand binding by cannabinoid ligands is an artefact due to the physicochemical properties of $\left[{ }^{125} \mathrm{I}\right] \mathrm{AB}$ MECA. It was therefore decided to use the radiolabelled antagonist $\left[{ }^{3} \mathrm{H}\right] \mathrm{PSB}-11$. In experiments analogous to those used with the radiolabelled agonist $\left[{ }^{125} \mathrm{I}\right] \mathrm{AB}$ MECA, the ability of increasing concentrations of either ACPA, 2-AG or AM 251 to displace $\left[{ }^{3} \mathrm{H}\right]$ PSB-11 binding was assessed. In the case of both ACPA and AM 251, a pIC fo $_{50} \sim 4.8$ was gained, and steep curves with high Hill coefficients were observed (table 1, figure 4). The endogenous ligands 2-AG and anandamide show a lower potency for the inhibition of $\left[{ }^{3} \mathrm{H}\right] \mathrm{PSB}-11$ with a $\mathrm{pIC}_{50}$ of $4.16 \pm 0.11$ and $4.25 \pm 0.12$ respectively. Again high Hill coefficients were observed for both 2-AG (4.1 \pm 0.4$)$ and anandamide (2.6 \pm 0.3$)$ and these Hill coefficients were significantly different from unity $(\mathrm{p}<$ $0.05)$. 


\subsection{Dissociation kinetic assays in $\mathrm{CHO} h \mathrm{~h}_{3}$ membranes}

The inhibition binding assays described above indicated that the cannabinoid ligands interact with the $\mathrm{hA}_{3}$ receptor at a site different from the orthosteric site and consequently in a manner that is non-competitive with both an agonist and an antagonist. Many compounds that allosterically affect the binding of orthosteric compounds such as $\left[{ }^{125} \mathrm{I}\right] \mathrm{AB}$ MECA at the $\mathrm{hA}_{3}$ receptor do so by altering the dissociation rate of these compounds from the receptor. To determine whether the various cannabinoids possess this ability, $\left[{ }^{125} \mathrm{I}\right] \mathrm{AB}$ MECA dissociation kinetic assays were performed. Complete dissociation of $\left[{ }^{125} \mathrm{I}\right]$ AB MECA measured using excess NECA (an agonist) was observed after 10 hours at $25^{\circ} \mathrm{C}$ (data not shown) and yielded a $\mathrm{k}_{\text {off }}$ of $0.007 \pm 0.0005 \mathrm{~min}^{-1}$ (table 3, figure 5). Repeating this experiment in the presence of $10 \mu \mathrm{M} 2-\mathrm{AG}$ or $10 \mu \mathrm{M}$ anandamide caused a significant increase in the rate of dissociation (table 3). Interestingly the above experiment performed in the presence of AM 251 or WIN 55212-2 ((R)-(+)-[2,3-Dihydro-5-methyl-3-(4-morpholinylmethyl)pyrrolo[1,2,3-de)-1,4benzoxazin-6-yl]-1-napthalenylmethanone)) yielded no increase in dissociation rate. The endocannabinoids 2-AG and anandamide are eicosanoids, in contrast to AM 251 or WIN 55212-2 which as a diarylpyrazole or (aminoalkyl)indole respectively have a chemically distinct structures. To see if this pattern is observed across all of the cannabinoid ligands used in this study a 'kinetic screen' was performed. In this screen dissociation was initiated again using excess NECA with or without the presence of the various cannabinoid ligands (figure 1). The dissociation was stopped at 120 minutes, a time-point that allows a good window to observe both the effects of allosteric enhancers and inhibitors. Again in this one point screen it can be noticed that 2-AG causes a two fold decrease in the amount of $\left[{ }^{125} \mathrm{I}\right] \mathrm{AB}$ MECA bound as compared to excess NECA alone. This is consistent with the increased rate of 
dissociation observed with the addition of $2-\mathrm{AG}$ observed in the full dissociation curve experiment. Similarly AM 251 showed a level of $\left[{ }^{125} \mathrm{I}\right]$ AB MECA binding that was not significantly different from the control experiment with the excess of unlabelled NECA alone and again this is consistent with previous full curve experiments. The eicosanoid ligands, which have a structure that is highly related to 2-AG (figure 1), produced a decrease in bound $\left[{ }^{125} \mathrm{I}\right] \mathrm{AB}$ MECA as compared to that of the excess NECA alone condition (data not shown). Conversely, cannabinoid ligands with a structure distinct from the eicosanoid structure such as CP 55940, GW 405833 and WIN55212-2 did not significantly change the amount of $\left[{ }^{125} \mathrm{I}\right]$ AB MECA bound as compared to the NECA control condition. In addition, the noneicosanoid lipid oleamide, which has been shown to be an allosteric enhancer of ligand binding at the serotonin receptors had no effect on the dissociation of $\left[{ }^{125} \mathrm{I}\right] \mathrm{AB}$ MECA. In summary then cannabinoid ligands with an eicosanoid structure are negative allosteric modulators of the $\mathrm{hA}_{3}$ receptor, a property which is not extended to cannabinoids of other chemical classes or indeed other lipids.

\subsection{Dissociation kinetic assays in $\mathrm{CHO}-\mathrm{h} \mathrm{A}_{1}$ membranes}

Dissociation kinetics experiments revealed an interesting and novel action of eicosanoid cannabinoid ligands as allosteric inhibitors at the human adenosine $A_{3}$ receptor. An obvious next experiment was to see if this effect could be observed for another adenosine receptor. The ability of the endocannabinoid 2-AG or the $\mathrm{CB}_{1}$ antagonist AM 251 to affect the dissociation rate of $\left[{ }^{125} \mathrm{I}\right] \mathrm{AB}$ MECA from $\mathrm{hA}_{1}-\mathrm{CHO}$ membranes was tested. Dissociation of $\left[{ }^{125} \mathrm{I}\right] \mathrm{AB}$ MECA from the $\mathrm{hA}_{1}$ adenosine receptor was best described using a two phase decay analysis ( $\mathrm{F}$ test, $\mathrm{P}<0.05$ ) with a $\mathrm{k}_{\text {fast }}$ of $0.26 \pm 0.1 \mathrm{~min}^{-1}$ and a $\mathrm{k}_{\text {slow }}$ of $0.029 \pm 0.02$ (table 4). 
The addition of $10 \mu \mathrm{M}$ AM 251 or $10 \mu \mathrm{M} 2-\mathrm{AG}$ did not significantly affect either the rates of the fast or slow phases of dissociation. This demonstrates that the action of eicosanoid cannabinoids as negative allosteric enhancers is specific to the $\mathrm{hA}_{3}$ adenosine receptor and is perhaps not a general effect observed at all adenosine receptors or indeed all GPCRs.

\subsection{Dissociation kinetic assays in $\mathrm{CHO}-\mathrm{h} \mathrm{A}_{3}$ membranes using the radiolabelled antagonist $\left[{ }^{3} \mathrm{H}\right]$ PSB-11}

Since both anandamide and 2-AG inhibit the binding of the antagonist $\left[{ }^{3} \mathrm{H}\right] \mathrm{PSB}-11$ to the $\mathrm{hA}_{3}$ adenosine receptor, it was interesting to investigate the effect of $10 \mu \mathrm{M} 2-\mathrm{AG}$ on the dissociation of $\left[{ }^{3} \mathrm{H}\right]$ PSB-11 from $\mathrm{CHO}$ membranes expressing the $\mathrm{hA}_{3}$ receptor. Furthermore since 2-AG displays a lower potency in its ability to displace $\left[{ }^{3} \mathrm{H}\right]$ PSB-11 binding as compared to $\left[{ }^{125} \mathrm{I}\right] \mathrm{AB}$ MECA binding the effect of $100 \mu \mathrm{M} 2-\mathrm{AG}$ was also tested.

Dissociation kinetics experiments demonstrate that the addition of $10 \mu \mathrm{M} 2-\mathrm{AG}$ or indeed 100 $\mu \mathrm{M} 2-\mathrm{AG}$ has no effect on the rate of dissociation of $\left[{ }^{3} \mathrm{H}\right] \mathrm{PSB}-11$ (control $\mathrm{k}_{\mathrm{off}}=0.31 \pm 0.02$ $\left.\min ^{-1},+10 \mu \mathrm{M} 2-\mathrm{AG} \mathrm{k}_{\text {off }}=0.29 \pm 0.01 \mathrm{~min}^{-1},+100 \mu \mathrm{M} 2-\mathrm{AG} \mathrm{k}_{\text {off }}=0.32 \pm 0.02\right)$. This suggests that 2-AG is a negative allosteric modulator of agonist but not antagonist binding.

\subsection{The addition of $10 \mu \mathrm{M}$ 2-AG causes both a decrease in basal $\mathrm{h} \mathrm{A}_{3}$ adenosine receptor signalling and a six fold decrease in the potency of the full agonist Cl-IB-MECA.}

The addition of $10 \mu \mathrm{M}$ and $100 \mu \mathrm{M} 2-\mathrm{AG}$ to forskolin stimulated $\mathrm{hA}_{3}-\mathrm{CHO}$ cells caused a concentration dependent and significant increase in cAMP levels (figure 6Ai). Interestingly when a parallel experiment was performed on $\mathrm{CHO}$ cells that did not express the $\mathrm{hA}_{3}$ 
adenosine receptor, no such increase occurred (figure 6A ii). This suggests that the increase in forskolin-stimulated cAMP levels caused by the addition of 2-AG is mediated by a direct interaction of 2-AG with the $\mathrm{hA}_{3}$ receptor and not via an interaction with adenylate cyclase. We extended these studies to monitor the effect of increasing concentrations of the full agonist $\mathrm{Cl}$-IB-MECA on the intracellular cAMP levels of $\mathrm{hA}_{3}-\mathrm{CHO}$ cells with and without the addition of $10 \mu \mathrm{M} 2-\mathrm{AG}$ or the non-eicosanoid inverse agonist AM 251 (figure 6B). Again, with the addition of $10 \mu \mathrm{M} 2-\mathrm{AG}$ a decrease in basal $\mathrm{hA}_{3}$ receptor signalling was observed. Furthermore, $10 \mu \mathrm{M}$ 2-AG caused a six fold decrease in the potency of Cl-IBMECA from $23 \pm 13 \mathrm{nM}$ to $135 \pm 36 \mathrm{nM}$, (P <0.05, Student's t-test, Graphpad Prism version 5). Interestingly, this apparent antagonism could not be overcome with an increased concentration of Cl-IB-MECA. This is consistent with the allosteric nature of the interaction of $2-\mathrm{AG}$ with the $\mathrm{hA}_{3}$ receptor shown by ligand binding studies. In contrast the addition of AM 251 had no significant effect on the potency of Cl-IB-MECA (16 nM \pm 5 , Student's ttest, Graphpad prism version 5).

\section{Discussion}


This study demonstrates a direct interaction of endocannabinoid ligands with the adenosine $\mathrm{A}_{3}$ receptor which leads to the inhibition of ligand binding. Our study suggests that this is an allosteric effect rather than a direct competition with the orthosteric binding site of the $\mathrm{A}_{3}$ receptor. Accordingly kinetic studies and functional studies demonstrate that eicosanoids act as allosteric inhibitors at the $\mathrm{A}_{3}$ receptor. These studies were extended to demonstrate that the endocannabinoid 2-AG exerts its affect via a distinct site to two previously characterised allosteric modulators of the adenosine $\mathrm{A}_{3}$ receptor.

The direct effects of endocannabinoid ligands tested at the $\mathrm{A}_{3}$ receptor expressed in $\mathrm{CHO}$ cell membranes resulted in inhibition of both agonist $\left(\left[{ }^{125} \mathrm{I}\right] \mathrm{AB}\right.$ MECA $)$ and antagonist $\left(\left[{ }^{3} \mathrm{H}\right]\right.$ PSB-11) binding that was characterised by very steep inhibition curves. This is not in accord with simple mass action kinetics, indicating a non-competitive mode of interaction. Furthermore in the case of 2-AG $\left[{ }^{125} \mathrm{I}\right] \mathrm{AB}$ MECA binding was not reduced to nonspecific binding levels. Again this is characteristic of an allosteric interaction, as opposed to that of a competitive antagonist [24]. To confirm this we performed competition assays of increasing concentrations of NECA with $\left[{ }^{125} \mathrm{I}\right] \mathrm{AB}$ MECA. This revealed no effect of the endocannabinoid 2-AG on the potency of NECA, but was characterised by a non-competitive reduction in the total binding. This is consistent with an effect on the maximal number of $\mathrm{A}_{3}$ binding sites but not affinity. Similar results were obtained for saturation binding of [125I] $\mathrm{AB}$ MECA to hA3-CHO membranes. In the presence of increasing concentrations of 2-AG no change in affinity was observed, simply a concentration dependent decrease in $\mathrm{B}_{\max }$. However, at the adenosine $\mathrm{A}_{1}$ receptor the addition of $10 \mu \mathrm{M}$ 2-AG showed no effect on ligand binding suggesting that the effect is specific for the adenosine $A_{3}$ receptor. This specificity allows us to discount such effects as micellar formation, or the coating of the 
receptor surface by the hydrophobic cannabinoid ligands. Furthermore, the lipid oleamide did not displace $\left[{ }^{125} \mathrm{I}\right] \mathrm{AB}$ MECA binding at the $\mathrm{hA}_{3}$ adenosine receptor. This underlines the specificity of the observed effect both in terms of the $\mathrm{hA}_{3} \mathrm{R}$ and the eicosanoid ligands described. Cannabinoid ligands have been shown to alter membrane fluidity [25, 26]. Our results could be reconciled with a mechanism of action for the cannabinoid ligands that occurs via membrane perturbation affecting the functioning of membrane-associated proteins such as GPCRs. To test this hypothesis we monitored the effect of benzyl alcohol, an agent which is frequently used to disrupt membranes[27], on equilibrium binding of [ $\left.{ }^{125} \mathrm{I}\right] \mathrm{AB}$ MECA to $\mathrm{CHO}$ cell membranes expressing either $\mathrm{hA}_{1}$ or $\mathrm{hA}_{3}$ adenosine receptors. In both cases radioligand binding was inhibited in a concentration-dependent manner by benzyl alcohol (data not shown). This demonstrates that although increasing membrane fluidity or indeed causing membrane breakdown does inhibit radioligand binding at GPCRs it does so in a nonreceptor-subtype selective manner in contrast to $2 \mathrm{AG}$.

To further characterise the non-competitive action of the cannabinoid ligands in reducing $\left[{ }^{125} \mathrm{I}\right] \mathrm{AB}$ MECA binding, the ability of these ligands to influence the rate at which $\left[{ }^{125} \mathrm{I}\right] \mathrm{AB}$ MECA dissociates from the receptor was tested. Dissociation kinetic studies revealed that, whilst the eicosanoids increase the rate of ligand dissociation, other cannabinoids of unrelated structures do not. Ligands with an eicosanoid structure, including the endocannabinoids 2$\mathrm{AG}$ and anandamide act as negative allosteric modulators and increase the rate of dissociation of the agonist $\left[{ }^{125} \mathrm{I}\right] \mathrm{AB}$ MECA. This is in contrast to the previous findings of Christopoulos et al. who demonstrated that anandamide, whilst inhibiting radioligand binding at the muscarinic $\mathrm{M}_{1}$ and $\mathrm{M}_{4}$ receptors with high Hill coefficients, did not affect the rate of ligand dissociation [15]. We extended the study to monitor the effect of 2-AG on the rate of dissociation of the selective $\mathrm{hA}_{3}$ receptor antagonist $\left[{ }^{3} \mathrm{H}\right]$ PSB-11. No effect was observed 
using a concentration of $10 \mu \mathrm{M} 2-\mathrm{AG}$, suggesting that the endocannabinoid at such a concentration is a negative allosteric modulator of agonist but not antagonist binding at the human $A_{3}$ receptor. Similarly the potency of the inhibition antagonist binding by 2-AG was much lower than that observed for agonist binding. This suggests then that 2-AG modulates agonist binding to a greater extent than antagonist binding.

It was of importance to assess the effect of $2-\mathrm{AG}$ on the function of the $\mathrm{hA}_{3}$ adenosine receptor. By monitoring intracellular cAMP levels in the presence of increasing concentrations of the agonist Cl-IB-MECA the dose dependent inhibition of forskolin stimulated cAMP mediated by the $\mathrm{hA}_{3}$ receptor was demonstrated. With the addition of 10 $\mu \mathrm{M} 2$-AG we observed both a decrease in basal $\mathrm{hA}_{3} \mathrm{R}$ signalling and a six fold decrease in the potency of Cl-IB-MECA. This finding is in complete agreement with the data from our radioligand binding studies. Thus, $2-\mathrm{AG}$ acts as an allosteric inhibitor of $\mathrm{hA}_{3} \mathrm{R}$ ligand binding and function. In contrast AM 251 a non-eicosanioid ligand, displays no effect on the potency of Cl-IB-MECA. Interestingly this compound along with all other tested non-eicosanoid ligands has no effect on ligand dissociation. Therefore both kinetic binding and functional studies suggest that although all tested cannabinoid ligands did inhibit ligand binding at the hA3 receptor, a different mechanism and/or binding site may exist for the non-eicosanoid ligands as compared to the eicosanoid ligands. It should be noted that both anandamide and 2-AG are metabolically unstable and may be broken down into the eicosanoid arachidonic acid. However, it has been demonstrated that $\mathrm{CHO}$ cells (as used in this study) do not possess a 2-AG removal mechanism and therefore the potential breakdown of this eicosanoids should not influence the findings reported in this study [28]. The results of this study could be reconciled with cannabinoid ligands influencing receptor binding via their interaction with a cannabinoid receptor such as $\mathrm{CB}_{1}, \mathrm{CB}_{2}$ or indeed GPR55 which has recently revealed to be a 
novel cannabinoid receptor $[29,30]$. However, data from this study is not consistent with this explanation. Firstly in the cAMP experiments on 'empty' $\mathrm{CHO}$ cells no significant effect of 2-AG addition on the basal or forskolin stimulated conditions was observed. If either $\mathrm{CB}_{1}$ or $\mathrm{CB}_{2}$ cannabinoid receptors were expressed, a concentration dependent decrease in forskolin stimulated cAMP production would be expected consistent with their ability to activate $G_{i} G$ proteins. In contrast, in the $\mathrm{CHO}$ cell line expressing the $\mathrm{hA}_{3}$ receptor a significant decrease in forskolin stimulated cAMP was observed even in the absence of the $\mathrm{hA}_{3}$ adenosine receptor ligand. This would suggest a direct interaction with the $\mathrm{hA}_{3}$ receptor. Secondly, the inhibitory effect on ligand binding was not restricted to ligands with selectivity for a cannabinoid receptor subtype. In contrast a differential effect was observed dependant on ligand structure, with eicosanoid ligands only increasing the rate of ligand dissociation. Finally, $\mathrm{AM} 251$, an antagonist at the $\mathrm{CB}_{1}$ receptor, has recently been shown to activate GPR55 [31]. In contrast, 2 AG showed no effect at this receptor. Therefore the data presented in this study cannot be reconciled with an interaction with GPR55. The decrease in basal adenosine $A_{3}$ receptor activity observed upon the addition of $2 \mathrm{AG}$ suggests that the eicosanoid could be acting as an allosteric inverse agonist. However, the presence of adenosine causing this basal $\mathrm{hA}_{3}$ adenosine receptor signal cannot be ruled out.

The levels of the endocannabinoid anandamide in the brain can be raised in certain pathological states such as cerebral ischemia or schizophrenia $[17,19,20]$. 2-AG has been shown to have an affinity for cannabinoid receptors that is in the low micromolar range [2]. Accordingly this endocannabinoid is present in the brain at levels up to 800 times that of anandamide and again this level can be raised in ischemic conditions [17, 32, 33]. Consequently, the allosteric interaction of 2-AG and anandamide with the $\mathrm{hA} \mathrm{A}_{3} \mathrm{R}$ may be 
particularly relevant in these conditions. It is important to state that this interaction has yet to be demonstrated in vivo. However, numerous studies have suggested other sites of action of endocannabinoids in addition known cannabinoid receptors [10]. For example, cannabinoids inhibit the production of cytokines such as tumour necrosis factor- $\alpha$ from activated microglial cells but this activity does not involve any known cannabinoid receptor subtype for it occurs at high concentrations of ligands $[12,13]$. Interestingly, the expression of adenosine $\mathrm{A}_{3}$ receptors has been demonstrated in microglia [34]. More recently the important role of the adenosine $\mathrm{A}_{3}$ receptor in modulating Toll-like receptor mediated responses in microglia has been demonstrated [35]. This study would suggest that, by a direct interaction with the adenosine $\mathrm{A}_{3}$ receptor, the endocannabinoid 2-AG may modulate this role.

It should be noted that other endogenous allosteric modulators have been identified, such as endogenous cations, the peptide Leu-Ser-Ala-Leu acting on 5-HT $\mathrm{H}_{1 \mathrm{~B}}$ receptors and the amidated lipid oleamide acting on $5-\mathrm{HT}_{2}$ and $5-\mathrm{HT}_{7}$ receptors [36, 37]. Finally, most relevant to this work, the inhibition of ligand binding and function of muscarinic $\mathrm{M}_{1}$ and $\mathrm{M}_{4}$ receptors by anandamide has been shown to be non-competitive and mediated by a direct interaction with the muscarinic receptors $[15,16]$.

The recently published crystal structures of the $\beta_{2}$-adrenergic receptor, bound with the inverse agonists carazolol and timolol respectively, reveal a specific binding site for cholesterol molecules with the receptor. [38, 39]. In one study, incorporation of cholesterol induced an increase in affinity for an inverse agonist but did not affect agonist binding [39]. This illustrates that a change in the lipid environment of a receptor can modulate the ligand binding and function of that receptor. Increases in the levels of lipids such as 2-AG, then, may modulate receptor function via their specific interactions with that receptor. The modulation 
of the $h A_{3} R$ but not the $h A_{1} R$ demonstrates the selectivity of 2-AG, and suggests the presence of a specific binding site on the $\mathrm{hA}_{3} \mathrm{R}$. It is interesting to note that Hanson et al. find that the proposed cholesterol binding site is present in 44\% of class A GPCRs [39]. Again this demonstrates a degree of selectivity in the binding of cholesterol to certain GPCRs. As mentioned in the introduction, actions of endocannabinoids which are independent of their interaction with either $\mathrm{CB}_{1}$ or $\mathrm{CB}_{2}$ cannabinoid receptors are particularly well documented. The allosteric modulation of $\mathrm{G}$ protein-coupled receptors, including the adenosine $\mathrm{A}_{3}$ receptor, may thus represent yet another mechanism by which endocannabinoid ligands exert their physiological effects independently of their interaction with $\mathrm{CB}_{1}$ or $\mathrm{CB}_{2}$ cannabinoid receptors.

\section{Acknowledgments}

We thank Prof C.E. Müller (University of Bonn, Germany) for providing us with [ $\left.{ }^{3} \mathrm{H}\right]$ PSB11. 


\section{References}

[1] Fredholm BB, AP IJzerman, Jacobson KA, Klotz KN, Linden J. International Union of Pharmacology. XXV. Nomenclature and classification of adenosine receptors. Pharmacol Rev 2001;53:527-52.

[2] Howlett AC, Barth F, Bonner TI, Cabral G, Casellas P, Devane WA, et al. International Union of Pharmacology. XXVII. Classification of cannabinoid receptors. Pharmacol Rev 2002;54:161-202.

[3] Zhou QY, Li C, Olah ME, Johnson RA, Stiles GL, Civelli O. Molecular cloning and characterization of an adenosine receptor: the A3 adenosine receptor. Proc Natl Acad Sci U S A 1992;89:7432-6.

[4] Salvatore CA, Jacobson MA, Taylor HE, Linden J, Johnson RG. Molecular cloning and characterization of the human A3 adenosine receptor. Proc Natl Acad Sci U S A 1993;90:10365-9.

[5] Dixon AK, Gubitz AK, Sirinathsinghji DJ, Richardson PJ, Freeman TC. Tissue distribution of adenosine receptor mRNAs in the rat. Br J Pharmacol 1996;118:1461-8.

[6] Gessi S, Merighi S, Varani K, Leung E, Mac Lennan S, Borea PA. The A3 adenosine receptor: an enigmatic player in cell biology. Pharmacol Ther 2008;117:123-40. 
[7] Gao Z, Li BS, Day YJ, Linden J. A3 adenosine receptor activation triggers

phosphorylation of protein kinase $\mathrm{B}$ and protects rat basophilic leukemia $2 \mathrm{H} 3$ mast cells from apoptosis. Mol Pharmacol 2001;59:76-82.

[8] Pertwee RG. Inverse agonism and neutral antagonism at cannabinoid CB1 receptors. Life Sci 2005;76:1307-24.

[9] Vannacci A, Giannini L, Passani MB, Di Felice A, Pierpaoli S, Zagli G, et al. The endocannabinoid 2-arachidonylglycerol decreases the immunological activation of Guinea pig mast cells: involvement of nitric oxide and eicosanoids. J Pharmacol Exp Ther 2004;311:25664.

[10] Pertwee RG. The therapeutic potential of drugs that target cannabinoid receptors or modulate the tissue levels or actions of endocannabinoids. Aaps J 2005;7:E625-54.

[11] Di Marzo V, Breivogel CS, Tao Q, Bridgen DT, Razdan RK, Zimmer AM, et al. Levels, metabolism, and pharmacological activity of anandamide in $\mathrm{CB}(1)$ cannabinoid receptor knockout mice: evidence for non- $\mathrm{CB}(1)$, non- $\mathrm{CB}(2)$ receptor-mediated actions of anandamide in mouse brain. J Neurochem 2000;75:2434-44.

[12] Puffenbarger RA, Boothe AC, Cabral GA. Cannabinoids inhibit LPS-inducible cytokine mRNA expression in rat microglial cells. Glia 2000;29:58-69.

[13] Facchinetti F, Del Giudice E, Furegato S, Passarotto M, Leon A. Cannabinoids ablate release of TNFalpha in rat microglial cells stimulated with lypopolysaccharide. Glia $2003 ; 41: 161-8$ 
[14] Kimura T, Ohta T, Watanabe K, Yoshimura H, Yamamoto I. Anandamide, an endogenous cannabinoid receptor ligand, also interacts with 5-hydroxytryptamine (5-HT) receptor. Biol Pharm Bull 1998;21:224-6.

[15] Christopoulos A, Wilson K. Interaction of anandamide with the M(1) and M(4) muscarinic acetylcholine receptors. Brain Res 2001;915:70-8.

[16] Lanzafame AA, Guida E, Christopoulos A. Effects of anandamide on the binding and signaling properties of M1 muscarinic acetylcholine receptors. Biochem Pharmacol 2004;68:2207-19.

[17] Kurabayashi M, Takeyoshi I, Yoshinari D, Matsumoto K, Maruyama I, Morishita Y. 2-Arachidonoylglycerol increases in ischemia-reperfusion injury of the rat liver. J Invest Surg $2005 ; 18: 25-31$

[18] De Marchi N, De Petrocellis L, Orlando P, Daniele F, Fezza F, Di Marzo V.

Endocannabinoid signalling in the blood of patients with schizophrenia. Lipids Health Dis $2003 ; 2: 5$.

[19] Giuffrida A, Leweke FM, Gerth CW, Schreiber D, Koethe D, Faulhaber J, et al. Cerebrospinal anandamide levels are elevated in acute schizophrenia and are inversely correlated with psychotic symptoms. Neuropsychopharmacology 2004;29:2108-14.

[20] Muthian S, Rademacher DJ, Roelke CT, Gross GJ, Hillard CJ. Anandamide content is increased and CB1 cannabinoid receptor blockade is protective during transient, focal cerebral ischemia. Neuroscience 2004;129:743-50.

[21] Small-Howard AL, Shimoda LM, Adra CN, Turner H. Anti-inflammatory potential of CB1-mediated cAMP elevation in mast cells. Biochem J 2005;388:465-73. 
[22] Wittendorp MC, Boddeke HW, Biber K. Adenosine A3 receptor-induced CCL2 synthesis in cultured mouse astrocytes. Glia 2004;46:410-8.

[23] Van Veldhoven JP, Chang LC, Von Frijtag Drabbe Künzel JK, Mulder-Krieger T, Struensee-Link R, Beukers MW, et al. A new generation of adenosine receptor antagonists: From di- to trisubstituted aminopyrimidines. Bioorg Med Chem 2008;16:2741-52.

[24] Christopoulos A, Kenakin T. G protein-coupled receptor allosterism and complexing. Pharmacol Rev 2002;54:323-74.

[25] Bloom AS, Edgemond WS, Moldvan JC. Nonclassical and endogenous cannabinoids: effects on the ordering of brain membranes. Neurochem Res 1997;22:563-8.

[26] Tiburu EK, Bass CE, Struppe JO, Lorigan GA, Avraham S, Avraham HK. Structural divergence among cannabinoids influences membrane dynamics: a $2 \mathrm{H}$ solid-state NMR analysis. Biochim Biophys Acta 2007;1768:2049-59.

[27] Balogh G, Horvath I, Nagy E, Hoyk Z, Benko S, Bensaude O, et al. The hyperfluidization of mammalian cell membranes acts as a signal to initiate the heat shock protein response. Febs J 2005;272:6077-86.

[28] Gonsiorek W, Lunn C, Fan X, Narula S, Lundell D, Hipkin RW. Endocannabinoid 2arachidonyl glycerol is a full agonist through human type 2 cannabinoid receptor: antagonism by anandamide. Mol Pharmacol 2000;57:1045-50.

[29] Ryberg E, Larsson N, Sjogren S, Hjorth S, Hermansson NO, Leonova J, et al. The orphan receptor GPR55 is a novel cannabinoid receptor. Br J Pharmacol 2007;152:1092-101.

[30] Pertwee RG. GPR55: a new member of the cannabinoid receptor clan? Br J Pharmacol 2007;152:984-6. 
[31] Henstridge CM, Balenga NA, Ford LA, Ross RA, Waldhoer M, Irving AJ. The

GPR55 ligand L-alpha-lysophosphatidylinositol promotes RhoA-dependent $\mathrm{Ca} 2+$ signaling and NFAT activation. FASEB J 2009;23:183-93.

[32] Sugiura T, Kodaka T, Nakane S, Miyashita T, Kondo S, Suhara Y, et al. Evidence that the cannabinoid CB1 receptor is a 2-arachidonoylglycerol receptor. Structure-activity relationship of 2-arachidonoylglycerol, ether-linked analogues, and related compounds. J Biol Chem 1999;274:2794-801.

[33] Pertwee RG. The pharmacology of cannabinoid receptors and their ligands: an overview. Int J Obes (Lond) 2006;30 Suppl 1:S13-8.

[34] Hammarberg C, Schulte G, Fredholm BB. Evidence for functional adenosine A3 receptors in microglia cells. J Neurochem 2003;86:1051-4.

[35] van der Putten C, Zuiderwijk-Sick EA, van Straalen L, de Geus ED, Boven LA, Kondova I, et al. Differential expression of adenosine A3 receptors controls adenosine A2A receptor-mediated inhibition of TLR responses in microglia. J Immunol 2009;182:7603-12.

[36] Hedlund PB, Carson MJ, Sutcliffe JG, Thomas EA. Allosteric regulation by oleamide of the binding properties of 5-hydroxytryptamine7 receptors. Biochem Pharmacol 1999;58:1807-13.

[37] Thomas EA, Carson MJ, Neal MJ, Sutcliffe JG. Unique allosteric regulation of 5hydroxytryptamine receptor-mediated signal transduction by oleamide. Proc Natl Acad Sci U S A 1997;94:14115-9. 
[38] Cherezov V, Rosenbaum DM, Hanson MA, Rasmussen SG, Thian FS, Kobilka TS, et

al. High-resolution crystal structure of an engineered human beta2-adrenergic G proteincoupled receptor. Science 2007;318:1258-65.

[39] Hanson MA, Cherezov V, Griffith MT, Roth CB, Jaakola VP, Chien EY, et al. A specific cholesterol binding site is established by the 2.8 A structure of the human beta2adrenergic receptor. Structure 2008;16:897-905.

\section{Legends for Figures}

\section{Figure 1}

A summary of the structures of cannabinoid ligands used in this study, with both an eicosanoid and non-eicosanoid structure. Also included is the structure of oleamide, a non-eicosanoid lipid. The selectivity of the various ligands for eith cannabinoid CB1 or CB2 receptors is noted based on data from Pertwee (2006) Cannabinoid receptor ligands. Tocris Reviews No. 27

\section{Figure 2}

Displacement of $\left[{ }^{125} \mathrm{I}\right] \mathrm{AB}$ MECA by various cannabinoid ligands is characterised by high Hill coefficients.

The ability of the cannabinoid ligands 2-AG $(\boldsymbol{\Delta})$, AM $251(\bullet)$, anandamide $(\boldsymbol{\nabla})$ and ACPA (घ) to inhibit $0.1 \mathrm{nM}\left[{ }^{125} \mathrm{I}\right] \mathrm{AB}$ MECA binding at the $\mathrm{hA}_{3}$ expressed in $\mathrm{CHO}$ membranes was investigated. Incubation was for 3 hours at $25^{\circ} \mathrm{C}$ in Tris- $\mathrm{HCl}$ buffer $\mathrm{pH} 8.0,10 \mathrm{mM} \mathrm{MgCl}$,

\section{Figure 3}


The addition of $10 \mu \mathrm{M}$ 2-AG reduces maximal $\left[{ }^{125} \mathrm{I}\right] \mathrm{AB}$ MECA binding but does not change the affinity of an agonist at the $\mathrm{hA}_{3}$ adenosine receptor. Inhibition binding of the agonist NECA against $0.1 \mathrm{nM}\left[{ }^{125} \mathrm{I}\right] \mathrm{AB}$ MECA in the absence or presence of $10 \mu \mathrm{M} 2 \mathrm{AG}$ at the $\mathrm{hA}_{3}$ receptor expressed in $\mathrm{CHO}$ cell membranes. Incubation was for 3 hours at $25^{\circ} \mathrm{C}$ in $50 \mathrm{mM}$ Tris- $\mathrm{HCl}$ buffer $\mathrm{pH} 8.0,10 \mathrm{mM} \mathrm{MgCl}$, .

\section{Figure 4}

Displacement of the antagonist $\left[{ }^{3} \mathrm{H}\right]$ PSB-11 by various cannabinoid ligands is characterised by high Hill coefficients. Inhibition binding of 2-AG (•), anandamide ( $\bullet$ ), AM $251(\boldsymbol{\Delta})$ and ACPA $(\boldsymbol{\nabla})$ against $4 \mathrm{nM}\left[{ }^{3} \mathrm{H}\right]$ PSB-11 at the $\mathrm{hA}_{3}$ receptor expressed in $\mathrm{CHO}$ membranes. Incubation was for 2 hours at $25^{\circ} \mathrm{C}$ in $50 \mathrm{mM}$ Tris- $\mathrm{HCl}$ buffer, $10 \mathrm{mM}$ $\mathrm{MgCl}_{2}, 1 \mathrm{mM}$ EDTA pH 8.0.

\section{Figure 5}

The addition of $10 \mu \mathrm{M}$ 2-AG increases the rate of dissociation of $\left[{ }^{125} \mathrm{I}\right] \mathrm{AB}$ MECA from CHO membranes expressing the $\mathrm{hA}_{3}$ receptor. Membranes were incubated with $0.1 \mathrm{nM}$ $\left[{ }^{125} \mathrm{I}\right] \mathrm{AB}$ MECA at $25^{\circ} \mathrm{C}$ for 3 hours in $50 \mathrm{mM}$ Tris- $\mathrm{HCl}$ buffer $\mathrm{pH} 8.0,10 \mathrm{mM} \mathrm{MgCl}_{2}$, , before dissociation was started by addition of $10 \mu \mathrm{M}$ NECA alone $(\bullet)$, or in combination with

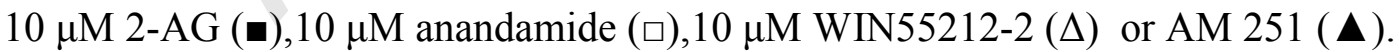
Normalised curves represent the best fit via non-linear regression analysis. Data points represent the mean \pm S.E.M. of three experiments conducted in duplicate.

\section{Figure 6}


A) The addition of $10 \mu \mathrm{M}$ and $100 \mu \mathrm{M}$ 2-AG causes a concentration-dependent increase in forskolin stimulated cAMP production in CHO cells expressing the human adenosine $A_{3}$ receptor (ii), but not in $\mathrm{CHO}$ cells with no adenosine $\mathrm{A}_{3}$ receptor expression (i). (Data was ananlysed using a one-way ANOVA with a bonferroni post-hoc test, significant differences are noted as follows: $\mathrm{p}<0.05-*, \mathrm{P}<0.01-* *, \mathrm{P}>0.001-* * *)$

B) The modulatory effects of $10 \mu \mathrm{M}$ 2-AG or $10 \mu \mathrm{M}$ AM 251 on the dose-response curve of CI-IB-MECA for the inhibition of the forskolin-stimulated cAMP production in CHO cells expressing the human adenosine $\mathbf{A}_{3}$ receptor. The addition of $10 \mu \mathrm{M} 2-\mathrm{AG}$ caused a significant, six-fold reduction in the potency of the full $\mathrm{hA}_{3} \mathrm{R}$ agonist Cl-IB-MECA from $23 \pm$ $13 \mathrm{nM}$ to $135 \pm 36 \mathrm{nM}$. The addition of $10 \mu \mathrm{M}$ AM 251 has no effect on the potency of CLIB-MECA $(16 \pm 5 \mathrm{nM}) .,(\mathrm{P}<0.05$, Student's t-test, Graphpad Prism version 5, representative graphs from three experiments performed in duplicate) 
Table 1

\section{Displacement of $\left[{ }^{125} \mathrm{I}\right]$ AB MECA or of $\left[{ }^{3} \mathrm{H}\right]$ PSB-11 from CHO membranes expressing} the $h \mathrm{~A}_{3}$ receptor by the cannabinoid ligands ACPA, anandamide, 2-AG and AM 251. Data are means $( \pm$ SEM) of 3 experiments performed in duplicate

\section{Displacement of $\left[{ }^{125}\right.$ I] AB MECA Displacement of $\left[{ }^{3} \mathrm{H}\right]$ PSB-11}

\begin{tabular}{lcccc}
\cline { 2 - 4 } AM 251 & $4.9 \pm 0.3$ & $3.2 \pm 0.2$ & $4.8 \pm 0.1$ & $3.2 \pm 1.1$ \\
Anandamide & $4.4 \pm 0.3$ & $3.49 \pm 0.3$ & $4.3 \pm 0.1$ & $2.6 \pm 0.3$ \\
ACPA & $5.3 \pm 0.1$ & $2.7 \pm 0.5$ & $4.8 \pm 0.2$ & $2.1 \pm 0.5$ \\
2-AG & $4.9 \pm 0.1$ & $3.5 \pm 0.7$ & $4.2 \pm 0.1$ & $4.1 \pm 0.4$
\end{tabular}


Table 2

Saturation binding of $\left[{ }^{125} \mathrm{I}\right] \mathrm{AB}$ MECA to CHO membranes stably expressing the hA3 receptor in the presence or absence of increasing concentrations of 2-AG. Data was analysed using a one-way anova with a bonferonni post-hoc test. Significant differences in Bmax as compared to the control condition are shown. No significant change in $K_{D}$ was observed $(\mathrm{p}<0.05-*, \mathrm{P}<0.01-* *, \mathrm{P}<0.001-* * *)$.

\begin{tabular}{lll} 
& $\mathbf{K}_{\mathbf{D}}, \mathbf{n M}$ & $\mathbf{B}_{\mathbf{m a x}}, \mathbf{p m o l . m}^{-\mathbf{1}}$ \\
\hline Control & $1.86 \pm 0.69$ & $1.16 \pm 0.28$ \\
$+1 \mu \mathrm{M} 2-\mathrm{AG}$ & $1.16 \pm 0.24$ & $0.68 \pm 0.08 *$ \\
$+3 \mu \mathrm{M} 2-\mathrm{AG}$ & $1.57 \pm 0.27$ & $0.56 \pm 0.06 * *$ \\
$+10 \mu \mathrm{M} 2-\mathrm{AG}$ & $0.93 \pm 0.15$ & $0.34 \pm 0.04 * * *$
\end{tabular}




\section{Table 3}

The dissociation of $\left[{ }^{125} \mathrm{I}\right] \mathrm{AB}$ MECA from CHO membranes expressing the $\mathrm{h} \mathrm{A}_{3}$ receptor with or without the presence of either 2 AG or AM 251. The rate and half life observed for conditions in which cannabinoid ligands were present at a concentration of $10 \mu \mathrm{M}$ were compared with the control (10 $\mu \mathrm{M}$ NECA only) condition using a one way ANOVA analysis with Bonferroni's post-hoc test, Graphpad prism 5. Data are means \pm SEM of three experiments were performed in duplicate. (Significant differences as compared to the $10 \mu \mathrm{M}$ NECA condition are noted as follows: *, $\mathrm{P}<0.05)$

\begin{tabular}{lll} 
& $\mathbf{k}_{\mathbf{o f f}}, \mathbf{~ m i n}^{-\mathbf{1}}$ & Half-Life, minutes \\
\hline $10 \mu \mathrm{M}$ NECA & $0.0069 \pm 0.0005$ & $100 \pm 6$ \\
$10 \mu \mathrm{M}$ NECA + $2 \mathrm{AG}$ & $0.0109 \pm 0.001 *$ & $72 \pm 3 *$ \\
$10 \mu \mathrm{M}$ NECA + Anandamide & $0.0102 \pm 0.003 *$ & $80 \pm 5 *$ \\
$10 \mu \mathrm{M}$ NECA + AM 251 & $0.0060 \pm 0.0005$ & $115 \pm 9$ \\
$10 \mu \mathrm{M}$ NECA + WIN 55212 & $0.0067 \pm 0.010$ & $108 \pm 10$
\end{tabular}




\section{Table 4}

The dissociation of $\left[{ }^{125} \mathrm{I}\right] \mathrm{AB}$ MECA from CHO membranes expressing the $\mathrm{h} \mathrm{A}_{1}$ receptor with or without the presence of either 2-AG or AM 251

\begin{tabular}{llll} 
& $\mathbf{1 0} \boldsymbol{\mu M}$ NECA & $\mathbf{1 0} \boldsymbol{\mu M}$ NECA + 2-AG & $\mathbf{1 0} \boldsymbol{\mu M}$ NECA + \\
& & & $\mathbf{A M 2 5 1}$ \\
\hline $\mathrm{k}_{\text {Fast }}$ & $0.26 \pm 0.1$ & $0.31 \pm 0.06$ & $0.27 \pm 0.18$ \\
$\mathrm{k}_{\text {Slow }}$ & $0.029 \pm 0.016$ & $0.028 \pm 0.093$ & $0.023 \pm 0.004$ \\
Half life fast, min & $2.98 \pm 1.05$ & $2.29 \pm 0.42$ & $3.21 \pm 2.12$ \\
Half life slow, min & $27.8 \pm 11.5$ & $23.6 \pm 6.12$ & $27.9 \pm 1.22$ \\
\% Fast & $34 \pm 2.61$ & $22.3 \pm 2.08$ & $41 \pm 17$
\end{tabular}




\section{Figure 1}

Eicosanoid cannabinoid receptor agonists

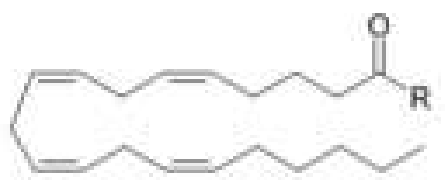

$A C E A, R=N H \frown C l$

CB1 selective agonist

ACPA, $\mathrm{R}=\mathrm{NH}^{-}$

CB1 selective agonist

2-AG, R $=\int_{0}^{\mathrm{OH}} \mathrm{OH}$

non-selective agonist

anandamide,

$\mathrm{R}=$ $\mathrm{NH} \sim \mathrm{OH}$

$\mathrm{CB} 1$ selective agonist

Non-eicosanoid lipid

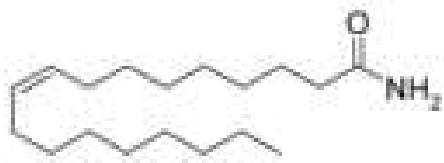

Oleamide

Non-eicosanoid

cannabinoid receptor agonists

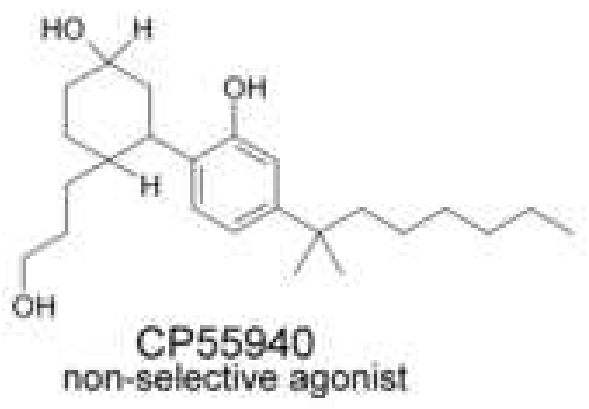

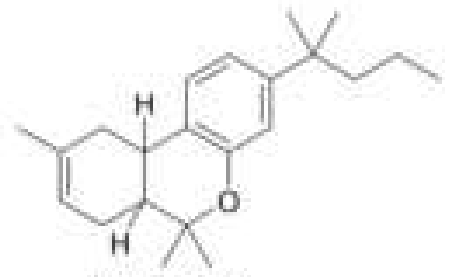

JWH 133

$\mathrm{CB} 2$ selective agonist<smiles>Cc1c(C(=O)c2ccc3ccccc3c2)c2cccc3c2n1C(CN1CCOCC1)CO3</smiles><smiles>Cc1c(CCN2CCOCC2)c2cc(O)ccc2n1C(=O)c1cccc(Cl)c1Cl</smiles>

WIN 55,212-2

GW 405833

non-selective agonist

$\mathrm{CB} 2$ selective agonist

Non-eicosanoid

cannabinoid receptor antagonists

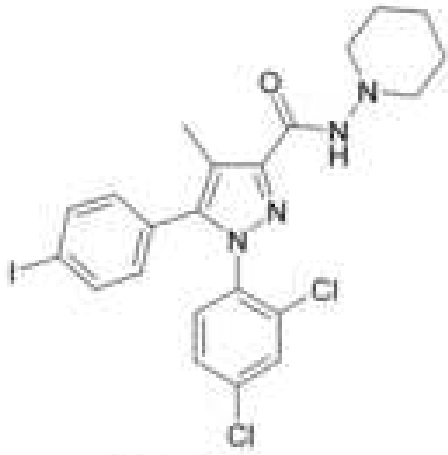

AM 251

CB1 selective antagonist<smiles>COc1ccc(C(=O)c2c(C)n(CCN3CCOCC3)c3cc(I)ccc23)cc1</smiles>

AM 630

$\mathrm{CB} 2$ selective antagonist 


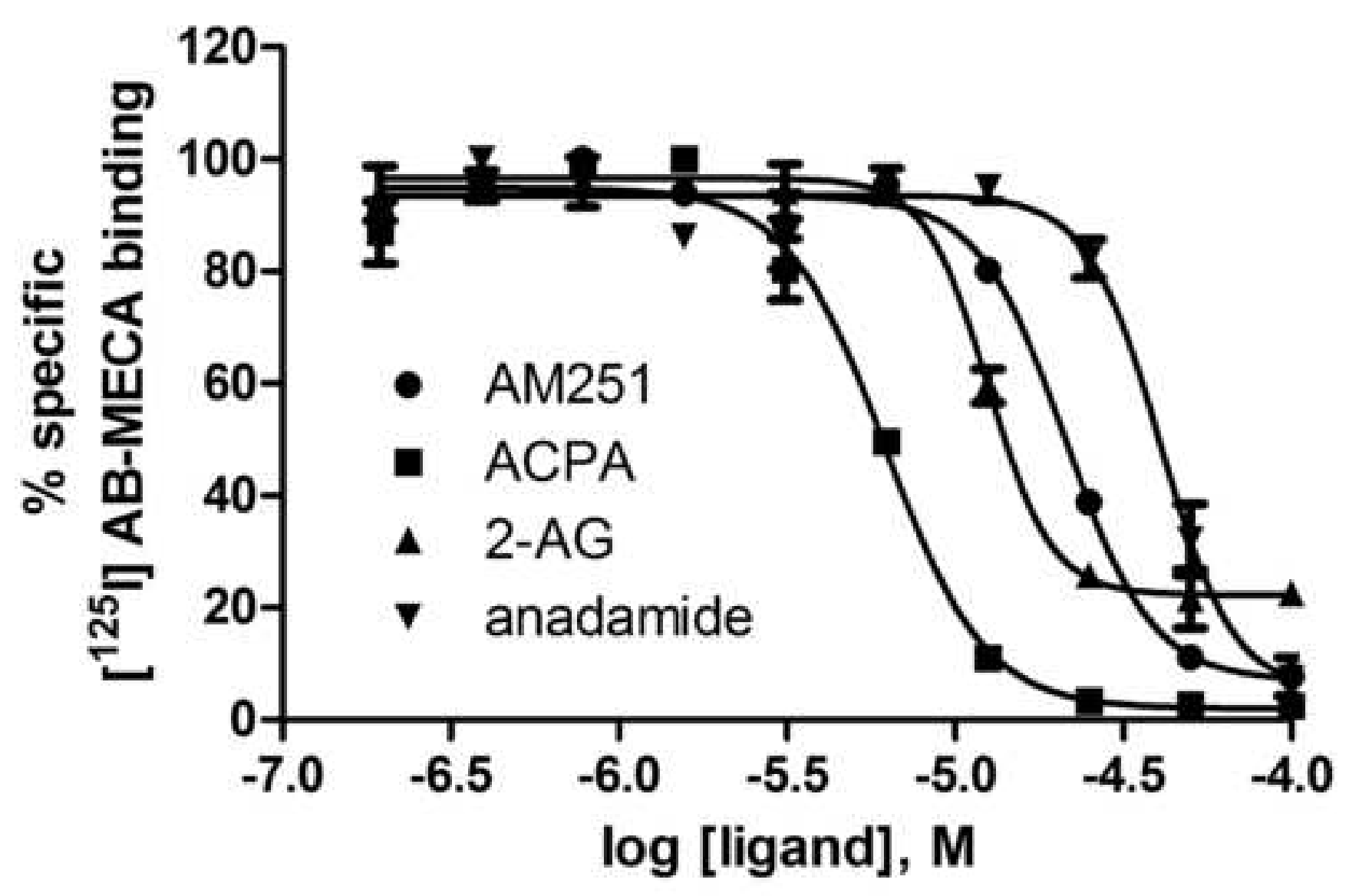

\section{Figure 2}


Figure 3

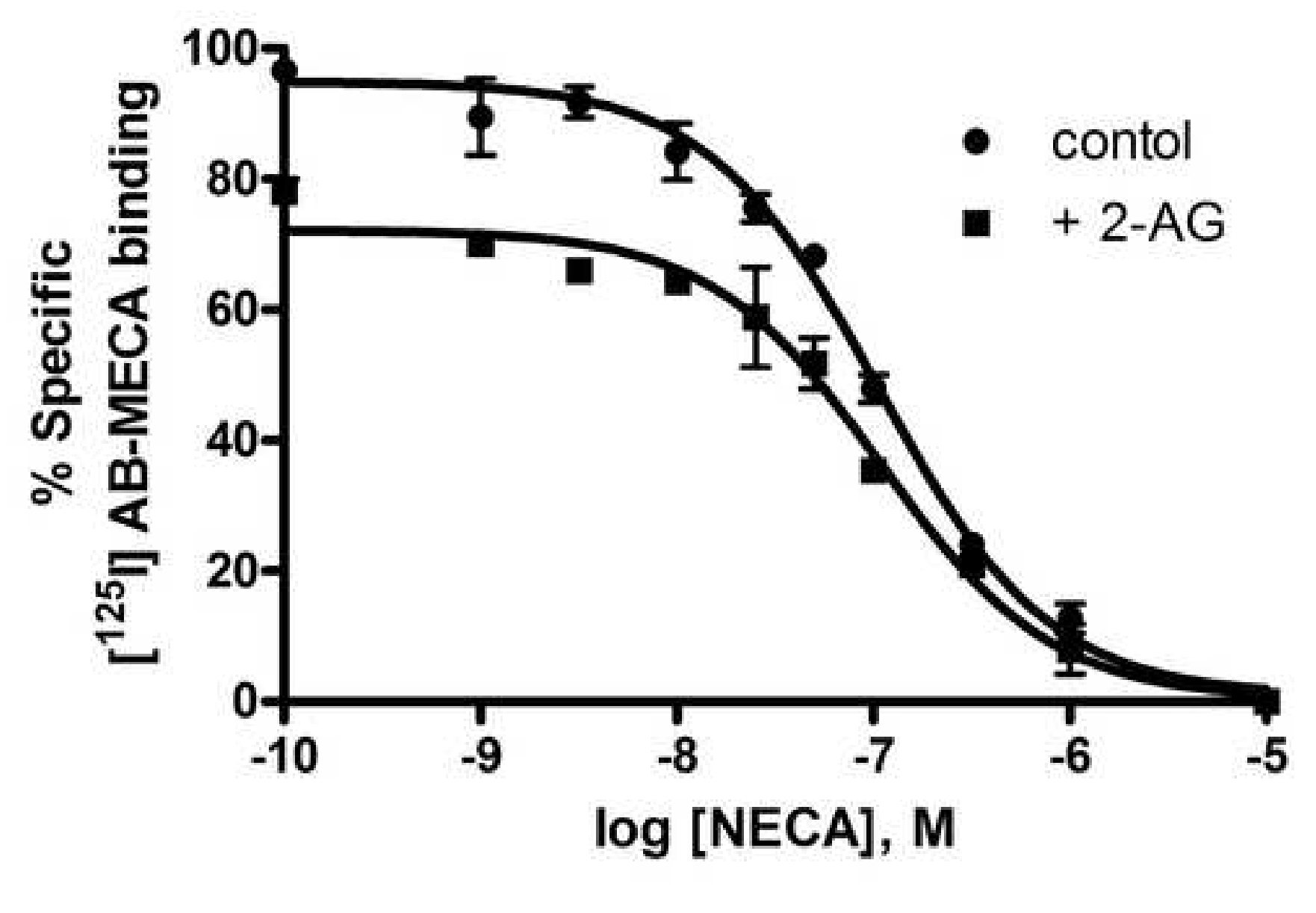

- contol $-5$

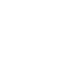


Figure 4

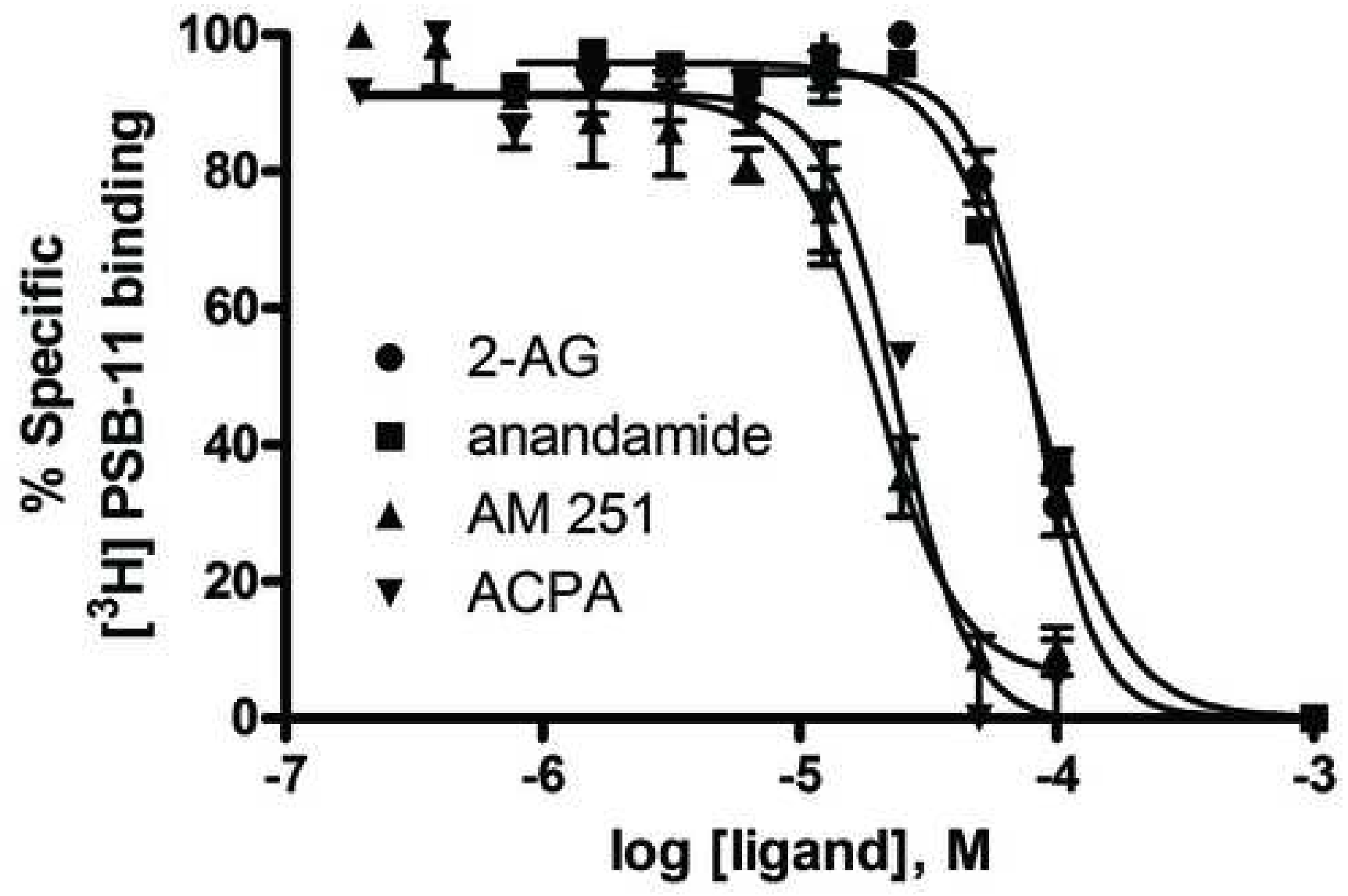


Figure 5

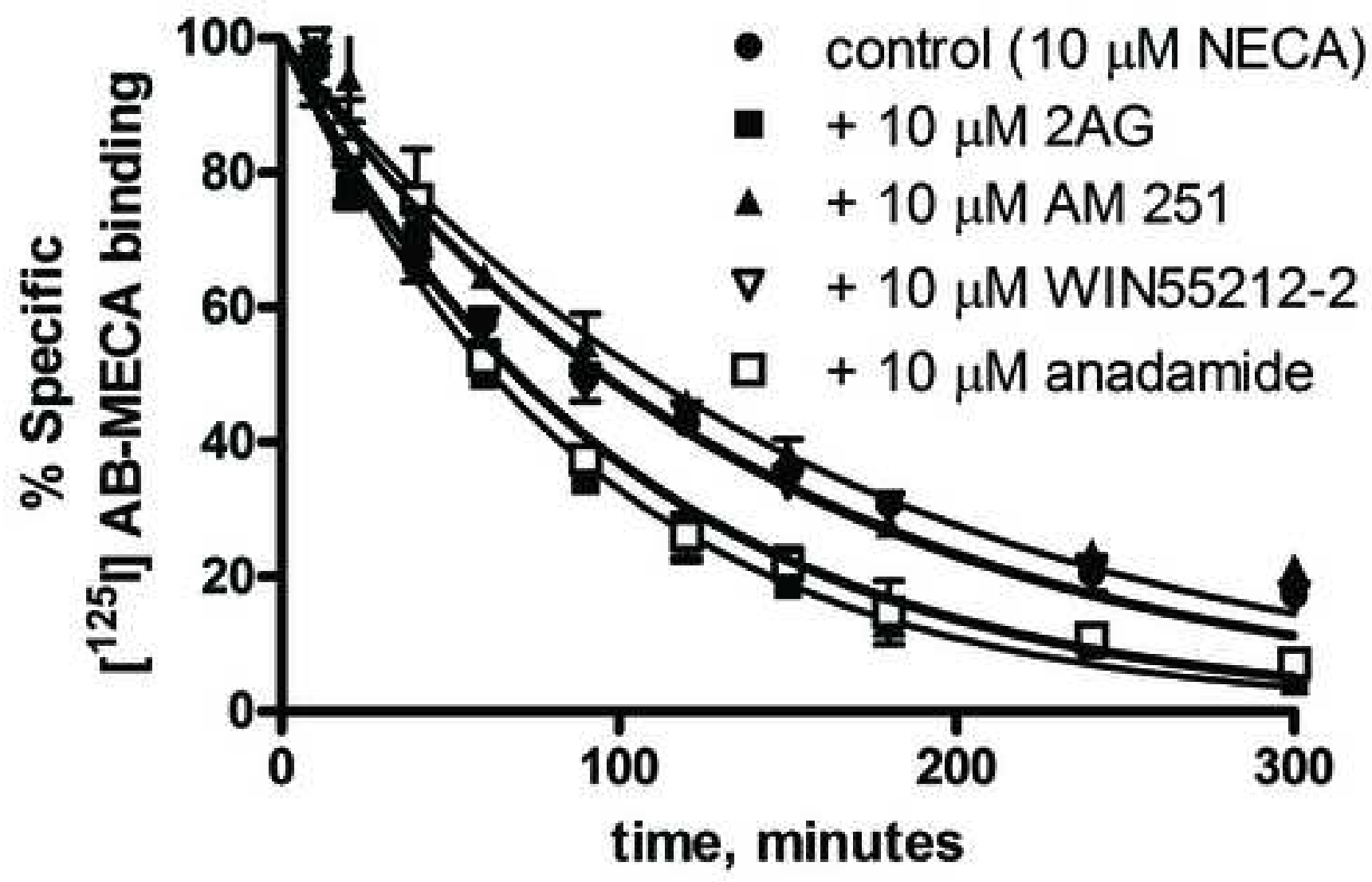


Figure 6

A)

i)

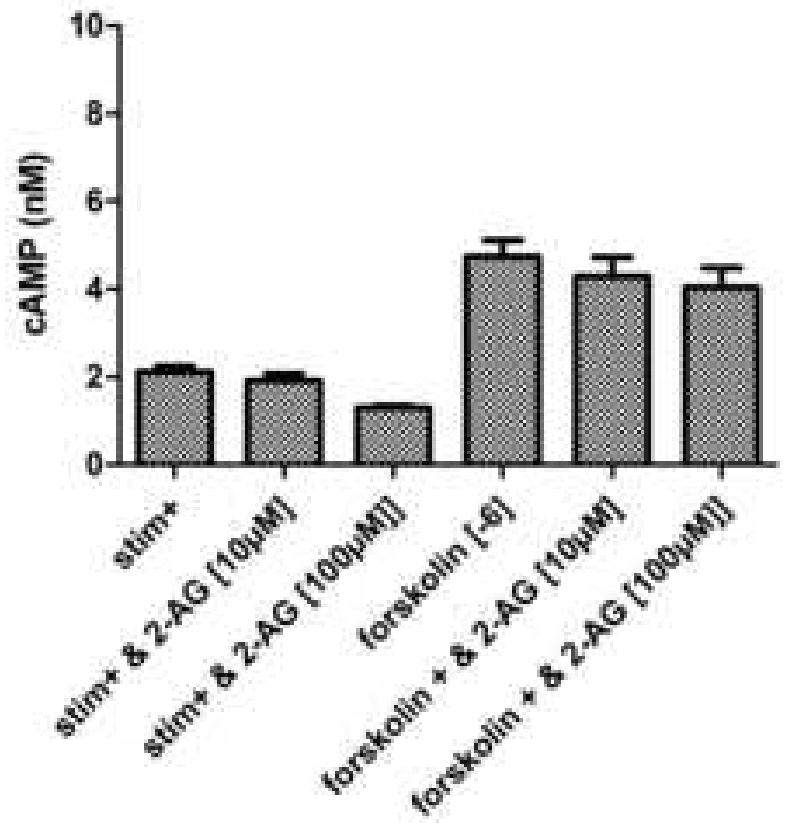

B)

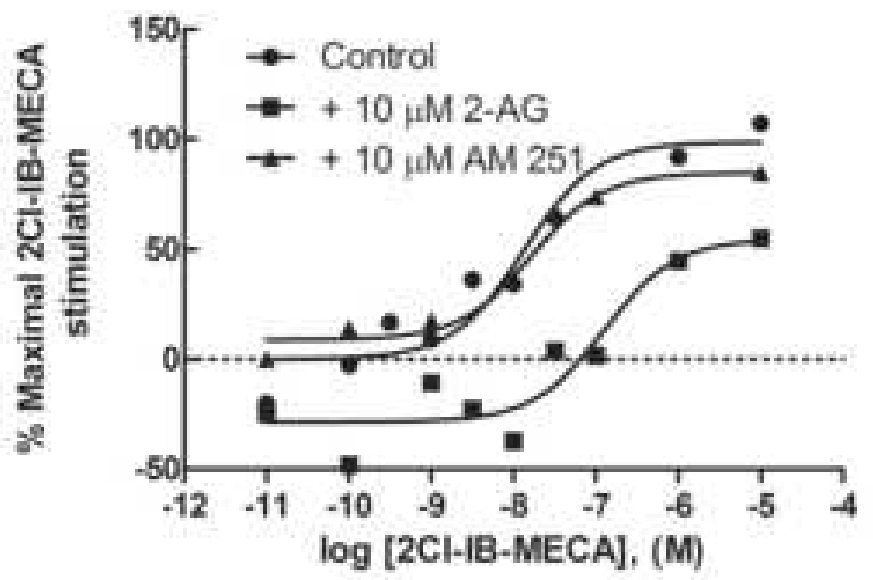

ii)

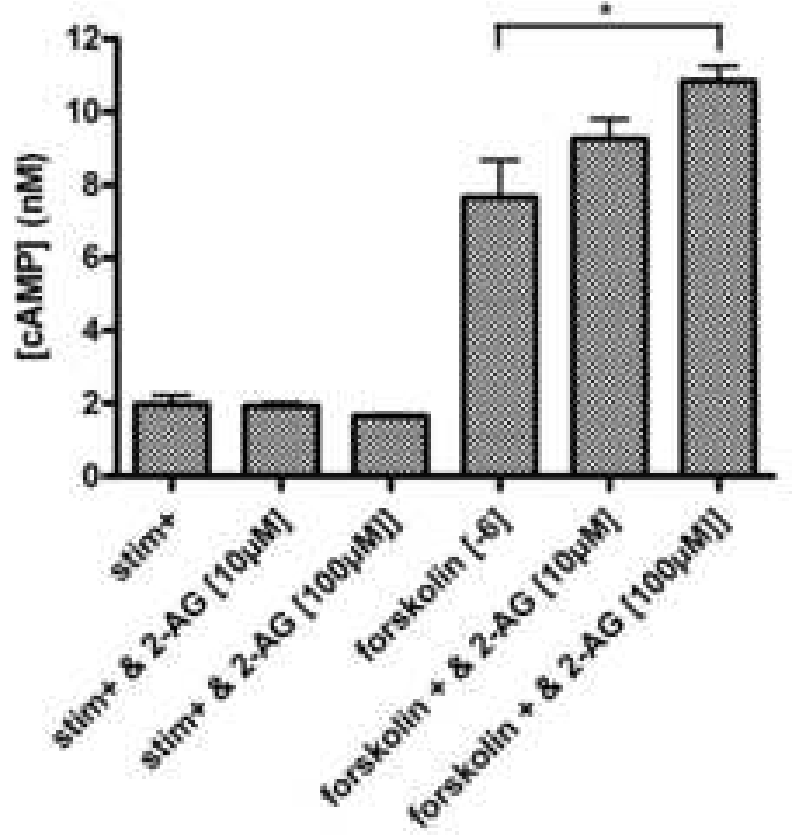


1) 2-arachidonlyglycerol inhibits agonist binding at the $\mathrm{hA}_{3}$ adenosine receptor

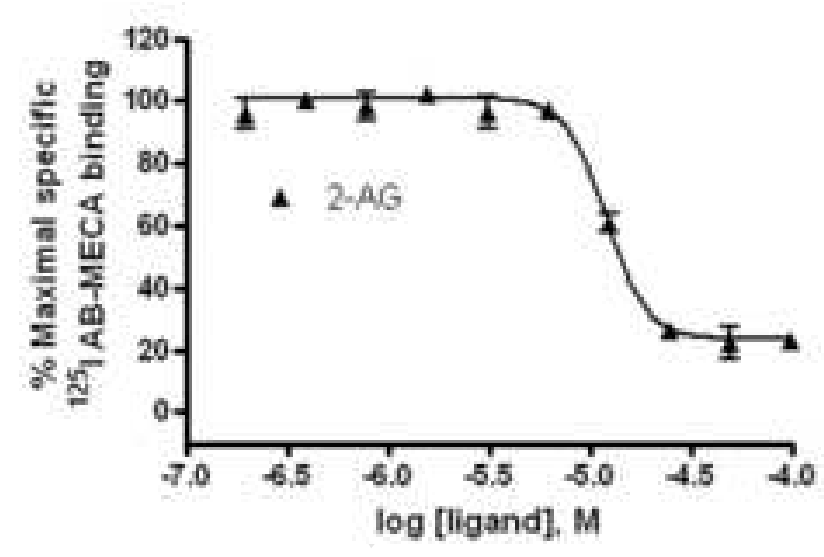

2) Kinetic binding studies and functional assays demonstrate that 2-AG is a negative allosteric modulator of the $\mathrm{hA}_{3}$ receptor

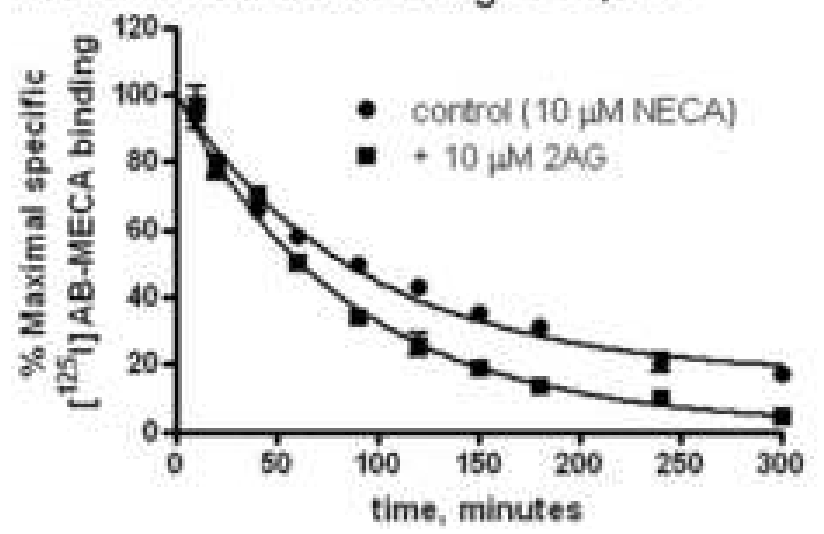

